\title{
Synthesis, crystal structures, and laser flash photolysis of 3-nitro-7a,15-methanonaphtho[1',2':6,7][1,3] oxazepino[3,2-a]indole derivatives
}

\author{
Greta Ragaitė, ${ }^{a}$ Vytas Martynaitis, ${ }^{b}$ Kipras Redeckas, ${ }^{c}$ Vladislava Voiciuk, ${ }^{c}$ \\ Mikas Vengris, ${ }^{c}$ and Algirdas Šačkus* ${ }^{* a, b}$ \\ ${ }^{a}$ Kaunas University of Technology, Department of Organic Chemistry, Radvilèu pl. 19, \\ Kaunas, LT-50254, Lithuania \\ ${ }^{b}$ Kaunas University of Technology, Institute of Synthetic Chemistry, Radvilenu pl. 19, \\ Kaunas, LT-50254, Lithuania \\ ${ }^{c}$ Vilnius University, Department of Quantum Electronics, Saulètekio al. 9, \\ LT-10222 Vilnius, Lithuania \\ E-mail: algirdas.sackus@,ktu.lt
}

DOI: $\underline{\text { http://dx.doi.org/10.3998/ark.5550190.p008.727 }}$

\begin{abstract}
The condensation of 1-substituted 9,9a-dihydro-1H-imidazo[1,2-a]indol-2(3H)-ones with 2hydroxy-6-nitro-1-naphthaldehyde afforded 1'-carbamoylmethyl-8-nitrospiro[benzo[f]chromene$3,2^{\prime}$-indole] derivatives, which underwent intramolecular cyclisation to derivatives of 3-nitro7a,15-methanonaphtho[1',2':6,7][1,3] oxazepino[3,2-a]indole upon treatment with a strong base. Laser excitation of the obtained uncoloured molecules of trans- and cis-3-nitro-7a,15-methanonaphtho[1',2':6,7][1,3] oxazepino[3,2-a]indole induced the formation of short-lived photogenerated species, which absorb in the visible spectrum and thermally revert to the ground state on a nanosecond time scale.
\end{abstract}

Keywords: Indoles, spiro[benzo[f]chromene-3,2'-indoles], [1,3]oxazepino[3,2-a]indoles, single crystal X-ray analysis, flash photolysis

\section{Introduction}

Derivatives of heterocyclic compounds are used widely in the preparation of chromogenic "smart materials". ${ }^{1-4}$ One of the most important classes of chromogenic materials is photochromic 6nitro-1', $3^{\prime}$-dihydrospiro[chromene-2,2'-indoles], also known in the literature as 6-nitrospiro[2 $\mathrm{H}$ 1-benzopyran-2,2'-indolines], which have been extensively studied due to their potential applications in various areas of materials science and advanced technologies. ${ }^{5-8}$ The aforementioned compounds under UV-irradiation undergo rapid $\mathrm{C}-\mathrm{O}$ bond cleavage, converting 
to the planar, coloured trans-merocyanine form. ${ }^{9,10}$ The synthesis of $1^{\prime}, 3^{\prime}$-dihydrospiro[chromene-2,2'-indoles] is usually based on the condensation of 2-methylideneindoline derivatives with such aryl aldehydes as 5-nitrosalicylaldehyde. ${ }^{1,11}$ Similar reactions of the aforementioned indolines with various 2-hydroxynaphthaldehydes afforded spiro[benzo[f]chromene-3,2'-indoles], which, like spiro[chromene-2,2'-indoles], change colour when subjected to such external stimulus as UV-irradiation or treatment with active nucleophiles. ${ }^{12-14}$

In our previous work, we showed that the condensation of 1-substituted imidazo[1,2-a]indolones with 2-hydroxy-1-naphthaldehyde gave 1-carbamoylmethylspiro[benzo[f]chromene$3,2^{\prime}$-indoles], which, under treatment with a strong base, underwent intramolecular cyclisation to bridged 7a,15-methanonaphtho[1',2':6,7][1,3] oxazepino[3,2-a]indole derivatives. ${ }^{15,16}$ The latter compounds were used in the preparation of imprinted polymer stationary phases. ${ }^{17}$

The aim of the present work is the synthesis and investigation of 3-nitro-7a,15-methanonaphtho[ $\left[1^{\prime}, 2^{\prime}: 6,7\right][1,3]$ oxazepino[3,2-a]indole derivatives. In principle, such compounds have the potential to exhibit chromogenic properties, as their structure includes the nitro-2,3-dihydro- $1 H$ benzo $[f]$ chromene structural unit, a source of the coloured 6-nitro-2-naphtholate chromophore. It was shown recently that the UV-laser excitation of such heterocyclic ring systems as 2-nitroindolo[2,1-b][1,3]benzoxazines or 6-nitro-1',3,3',4-tetrahydrospiro[chromene-2,2'-indoles] generates coloured zwitterionic species, which incorporate the $3 H$-indolium cation and the 4nitrophenolate anion. These photogenerated short-lived species are thermally unstable and revert to the ground state on a nanosecond time scale. ${ }^{18-21}$ Molecules of 5-nitronaphtho[2', $\left.1^{\prime}: 5,6\right]$ $[1,3]$ oxazino[2,3- $k]$ carbazole $\mathbf{1}$ under UV-laser excitation undergo a similar ring-opening to afford the unstable zwitterionic compound 2, possessing the 4-nitro-1-naphtholate chromophore, and revert to the closed form in a few nanoseconds (Scheme 1). ${ }^{22}$ Derivatives of nitroindolo[2,1$b][1,3]$ benzoxazines have found application in the development of photoswitchable fluorescent probes, ${ }^{23}$ luminescent quantum dots ${ }^{24}$ and chemosensors. ${ }^{25,26}$
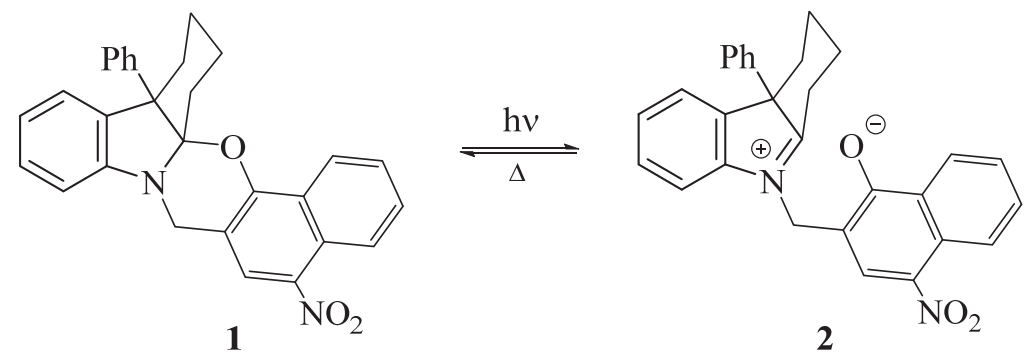

Scheme 1. Photochromism of nitronaphtho[1,3]oxazine derivative $\mathbf{1 .}$

\section{Results and Discussion}

The starting 1-substituted imidazo[1,2-a]indolones 4a-c were prepared by alkylation of compound 3a with benzyl chloride, allyl bromide and methyl iodide, as described elsewhere. ${ }^{27}$ 1,7-Dimethylimidazo[1,2-a]indolone $4 \mathbf{d}$ was obtained by a similar method by treatment of 
7-methylimidazo[1,2-a]indolone $\mathbf{3 b}$ with methyl iodide in DMF in the presence of $\mathrm{KOH}$ (Scheme 2).
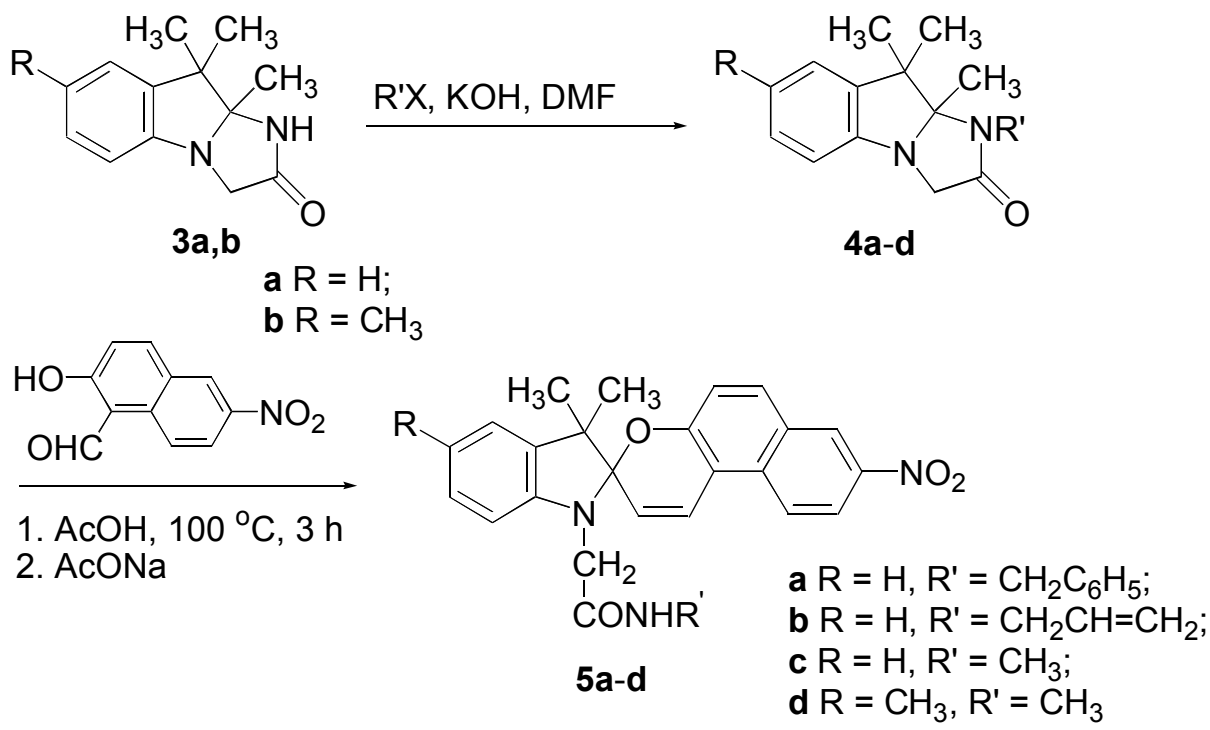

Scheme 2. Synthesis of 8-nitrospiro[benzo[f]chromene-3,2'-indoles].

The condensation of 1-substituted imidazo[1,2-a]indolones 4a-d with 2-hydroxy-6-nitro-1naphthaldehyde was carried out in acetic acid. Work-up of the reaction mixture with sodium acetate afforded 8-nitrospiro[benzo[f]chromene-3,2'-indoles] 5a-d. The ${ }^{1} \mathrm{H}$ NMR spectra of compounds 5a-d exhibited a characteristic doublet of the methynic proton in the area of 5.82$5.88 \mathrm{ppm}$ with vicinal ${ }^{3} \mathrm{~J}=10.5 \mathrm{~Hz}$ giving evidence for a cis-allocation of pyrane ring protons in the molecule. The corresponding ${ }^{13} \mathrm{C}$ NMR spectra contained the characteristic signal of the quaternary spiro-carbon at 105.0-105.3 (C-O) ppm.

When 8-nitrospiro[benzo[f]chromene-3,2'-indoles] 5a-d were heated with potassium hydroxide in ethanol, a mixture of the diastereomeric trans/cis-14,15-dihydro- $8 H-7 \mathrm{a}, 15$ methanonaphtho[1',2':6,7][1,3] oxazepino[3,2-a]indoles 6a-d and 7a-d was formed (Scheme 3). The assignments of trans/cis configurations to 6a-d and 7a-d were based on comparisons with ${ }^{1} \mathrm{H}$ NMR spectra of the most relevant compounds ${ }^{16,28,29}$ and data from single-crystal X-ray analyses. For example, the ${ }^{1} \mathrm{H}$ NMR spectrum of 6 a contained a singlet of $14-\mathrm{H}$ at $4.47 \mathrm{ppm}$ characteristic of the trans-diastereomer, while in the corresponding spectrum of 7a, the 14-H proton signal appeared as a doublet at $4.19 \mathrm{ppm}\left({ }^{3} J_{14,15}=4.2 \mathrm{~Hz}\right)$, confirming the cisconfiguration of the molecule. ${ }^{16,28}$ 


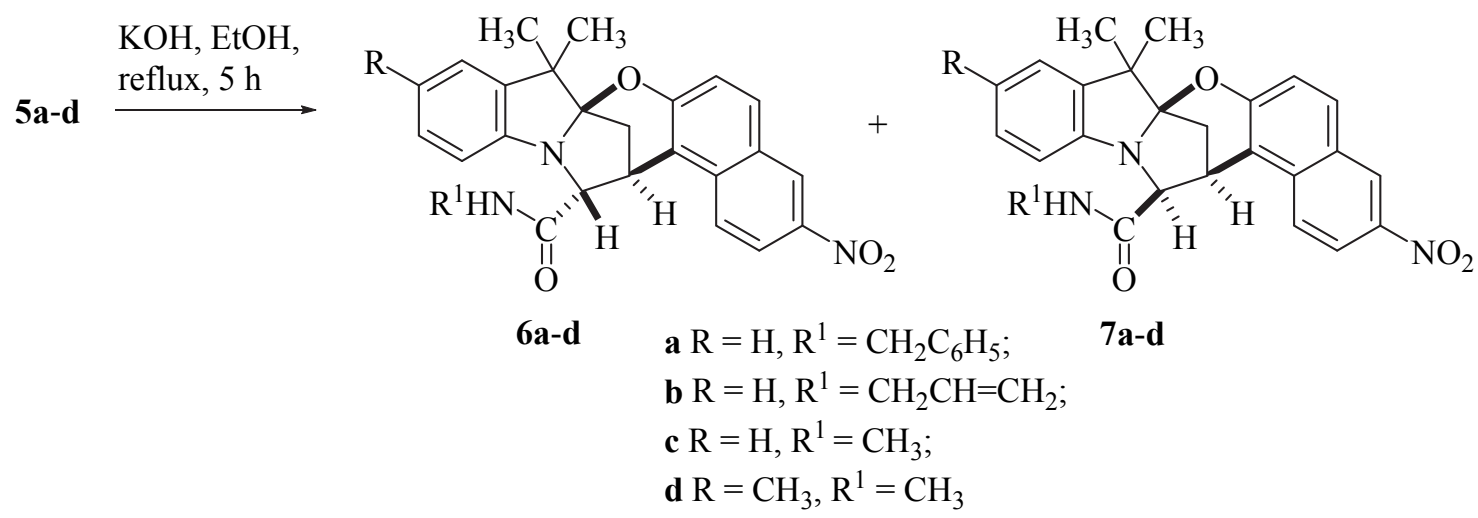

Scheme 3. Synthesis of trans- and cis-3-nitro-7a,15-methanonaphtho[ $\left[1^{\prime}, 2^{\prime}: 6,7\right][1,3]$ oxazepino$[3,2-a]$ indoles.

To obtain unequivocal evidence for configuration of compounds trans-6a and cis-7a, we performed single-crystal X-ray analyses of these compounds. The molecule of trans-6a consists of indoline and 3,4-dihydro- $2 H$-benzo[ $f]$ chromene structural units possessing common atoms with the central pyrrolidine ring (Figure 1, the crystallographic numbering does not represent the systematic numbering). ${ }^{30}$ The dihedral angle between the planes, in which the indole and 6-nitro2-naphthol units are situated, is $110^{\circ}$. The pyrrolidine hydrogen atoms at $\mathrm{C}(12)$ and $\mathrm{C}(13)$ are situated relative to the pyrrolidine ring plane in a mutual trans-disposition, while the dihedral angle $\mathrm{H}-\mathrm{C}(12)-\mathrm{C}(13)-\mathrm{H}$ is $98.16^{\circ}$. The sum of the indoline nitrogen valence angles is $356.21^{\circ}$ in trans-6a, indicating $s p^{2}$-dominant hybridisation of the valence electrons (ca. 88\%). The N(1)$\mathrm{C}(8)$ bond length is $1.395 \AA$ and corresponds to the bond length of aniline derivatives possessing $\mathrm{sp}^{2}$ hybridised nitrogens. ${ }^{31}$ The indoline nitrogen lone electron pair and the $\mathrm{C}(2)-\mathrm{O}(15)$ bond are in the same plane. The amide group is in an $s$-Z-conformation. The benzylic phenyl ring and the indole moiety are situated in almost parallel planes.

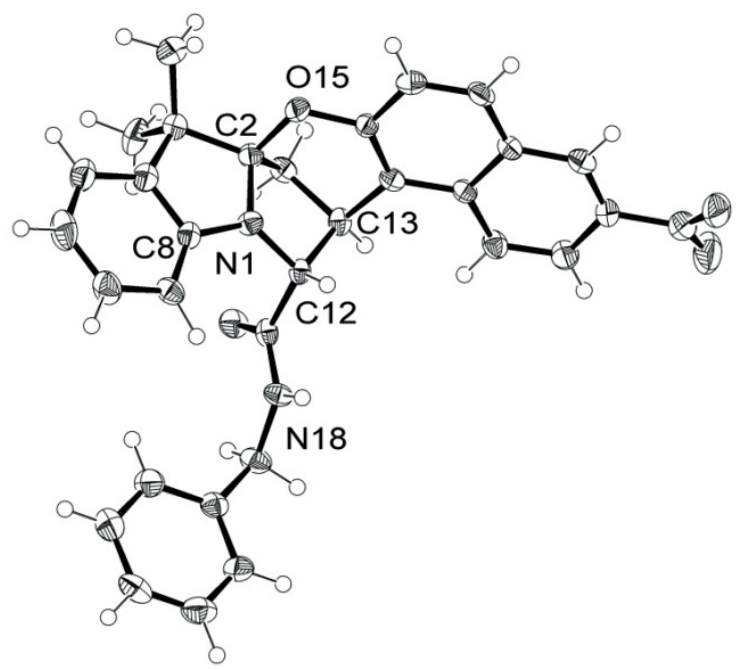

Figure 1. Ortep view of compound trans-6a. 


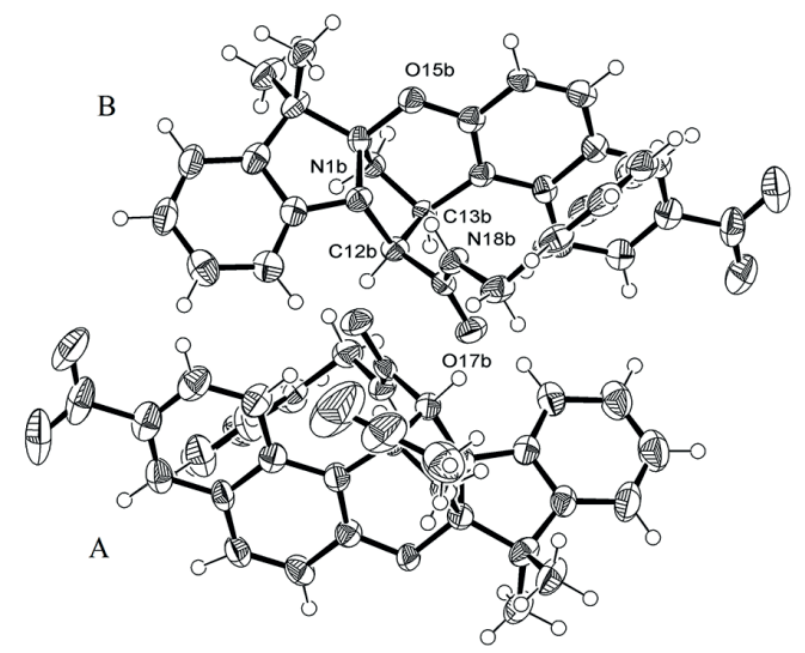

(a)

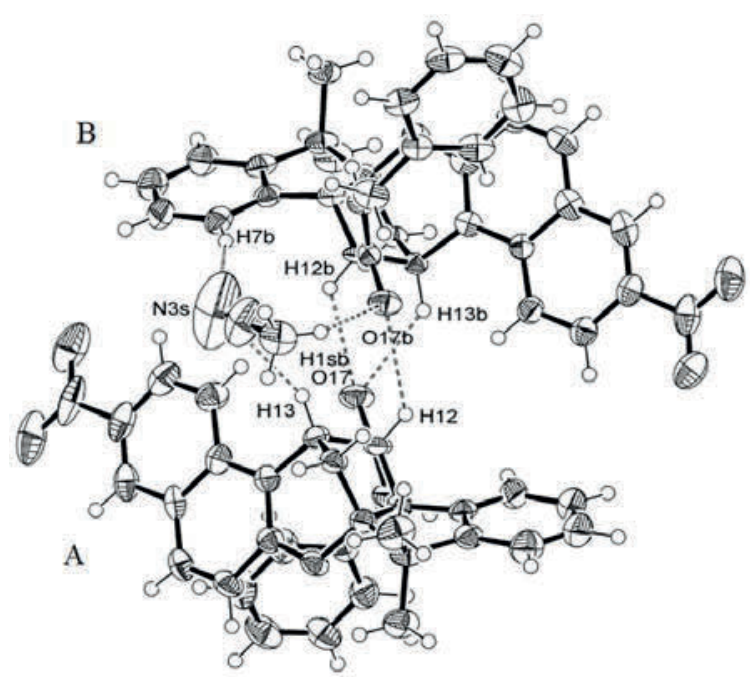

(b)

Figure 2. Ortep views of compound cis-7a: (a) view of the crystallographic forms $\mathbf{A}$ and $\mathbf{B}$ together with a molecule of acetonitrile; (b) view of hydrogen bonds in the asymmetric unit.

The asymmetric unit of cis-7a consists of the two independent crystallographic forms $\mathbf{A}$ and $\mathbf{B}$ of 7a and a molecule of the solvent, acetonitrile. ${ }^{32}$ Numbering of atoms is done only for form B for clarity, as the two structures are very similar, and the differences are minimal. The molecule of $c i s-7 \mathbf{a}$ involve the same structural units as the molecule trans-6a, but the dihedral angle between the planes in which the indoline and 3,4-dihydro- $2 H$-benzo[f]chromene structural units are situated is ca. $54^{\circ}$ (Figure 2). The pyrrolidine hydrogen atoms at $C(12 b)$ and $C(13 b)$ are situated relative to the pyrrolidine ring main plane in a mutual cis-disposition, while the dihedral angle $\mathrm{H}-\mathrm{C}(12 \mathrm{~b})-\mathrm{C}(13 \mathrm{~b})-\mathrm{H}$ is $33.8^{\circ}$. The sum of the indoline nitrogen valence angles is only $331.43^{\circ}$ in cis-7a, indicating that the nitrogen atom is tetrahedral (91\% sp ${ }^{3}$ hybridisation). The $\mathrm{C}(8 \mathrm{~b})-\mathrm{N}(1 \mathrm{~b})$ bond length is $1.432 \AA$, confirming the greater share of $\mathrm{sp}^{3}$ hybridised electrons in the corresponding bond formation. ${ }^{31}$ The amide moiety is in an $s-Z$ conformation, where the $\mathrm{C}=\mathrm{O}$ bond is in the anti-position to the $\mathrm{C}(12 \mathrm{~b})-\mathrm{N}(1 \mathrm{~b})$ bond. The acetonitrile molecule is held in the crystal by three hydrogen bonds connecting two crystallographically independent forms $\mathbf{A}$ and $\mathbf{B}$. Due to the asymmetrical distribution of hydrogen bonds (one bond with form $\mathbf{A}$ and two bonds with form B), the molecules of cis-7a have some small differences in these crystallographically independent forms. The angle between the phenyl ring and naphthalene moiety, for example, is $62^{\circ}$ in form $\mathbf{A}$ and $65^{\circ}$ in form $\mathbf{B}$.

The UV-Vis absorption spectra of $6 \mathbf{a}-\mathbf{d}$ and $7 \mathbf{a}$ from solutions in acetonitrile were obtained at room temperature. As a representative example, the steady-absorption spectrum of trans-6a is shown in Figure 3 (black curve). It shows a strong absorption band at 360-380 $\mathrm{nm}$ that has been assigned to the 6-nitro-2-naphthoxy moiety and resembles the ground-state absorption of nitronaphtho[1,3] oxazine derivative 1, possessing a 4-nitro-1-naphthoxy moiety. ${ }^{22}$ The steadystate absorption spectra of compounds $\mathbf{6 b - \mathbf { d }}$ and $\mathbf{7 a}$ were very similar (Table 1). 


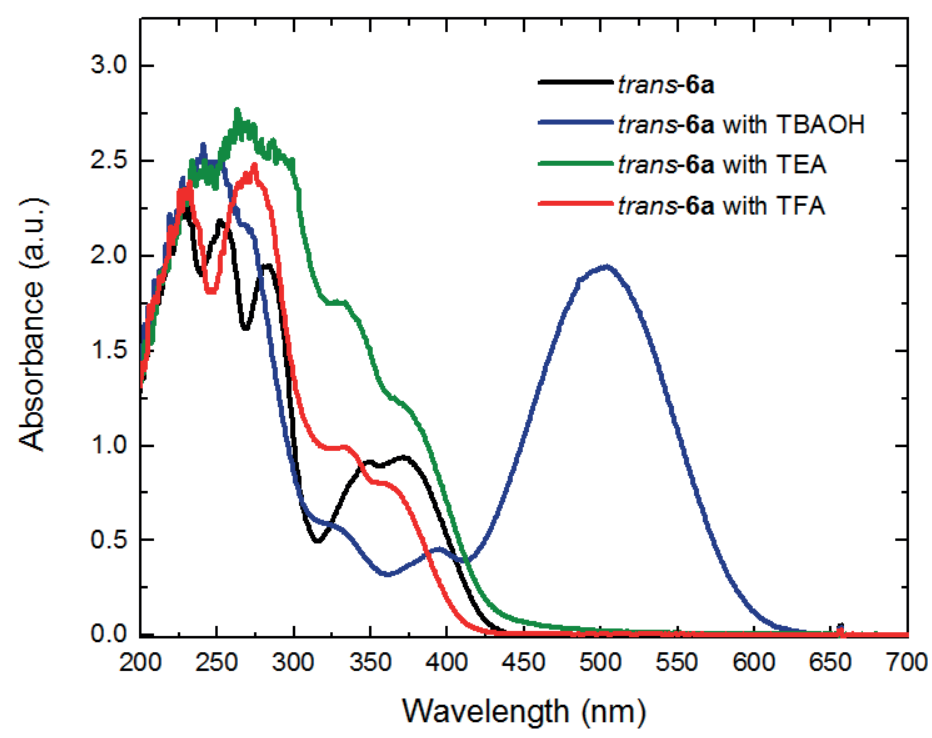

Figure 3. UV-Vis spectra of various forms of trans-6a in acetonitrile (black: 6a in pure acetonitrile, blue: chemically opened form of $\mathbf{6 a}$ with $\mathrm{TBAOH}$, green: $6 \mathbf{a}$ with TEA, red: chemically opened form of $6 \mathbf{a}$ with TFA).

When solutions of trans-6a-d in acetonitrile were treated with a two-fold excess of tetrabutylammonium hydroxide $(\mathrm{TBAOH})$, a coloured product with an absorption maximum at 490-505 nm, characteristic of the 6-nitro-2-naphtholate chromophore, ${ }^{22}$ was formed immediately (Table 1). As a representative example, the UV-Vis spectral behaviour of the compound trans-6a in acetonitrile after the addition of TBAOH is shown in Figure 3 (blue curve). However, adding a non-nucleophilic base, such as triethylamine, to a solution of trans-6a did not cause any absorption to appear in the visible part of the absorption spectrum (Figure 3, green curve). Therefore, the coloured form that appeared is presumably the adduct $\mathbf{8}$, formed via ring-opening and hydroxyl anion addition to the indole $\alpha$-carbon, as shown in Scheme 4 . It is known that the formation of similar pseudo-bases occurred when 1,2,3,3-tetrasubstituted $3 H$-indolium salts are treated with alkali. ${ }^{33,34}$ It should be noted that the steady-state absorption spectrum of 2-hydroxy6-nitronaphthaldehyde in acetonitrile exhibited absorption bands at 295 and $340 \mathrm{~nm}$ (Figure 4, black curve), while upon addition of TBAOH to the solution, a strong absorption band at $450 \mathrm{~nm}$ arose (Figure 4, blue curve) that indicates the formation of the corresponding nitronaphtholate anion.

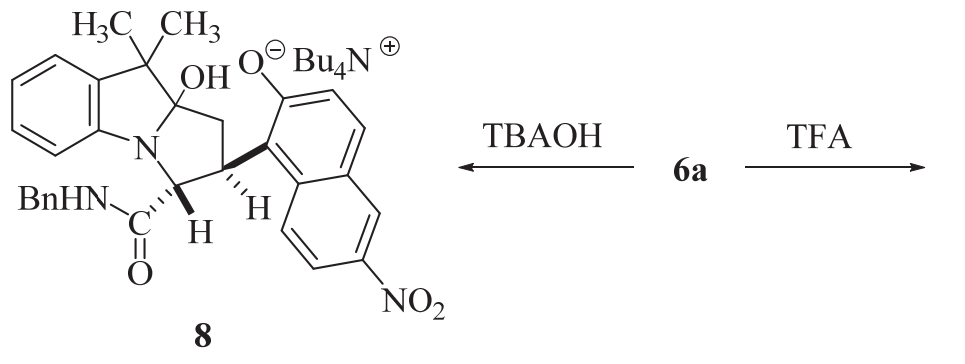

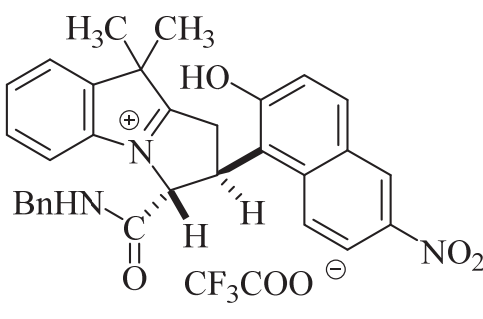

9

Scheme 4. Base and acid induced ring-opening reactions of trans-6a. 
Table 1. Absorption maxima $\left(\lambda_{\max }\right)$ and molar absorptivity $(\varepsilon)$ of 7a,15-methanonaphtho-$\left[1^{\prime}, 2^{\prime}: 6,7\right][1,3]$ oxazepino[3,2- $\left.a\right]$ indoles $\mathbf{6 a - d}$ and $\mathbf{7} \mathbf{a}$ in acetonitrile before and after addition of TBAOH

\begin{tabular}{|c|c|c|c|c|c|}
\hline Entry & Compound & $\lambda_{\max }(\mathrm{nm})$ & $\varepsilon\left(\mathrm{mM}^{-1} \mathrm{~cm}^{-1}\right)$ & $\begin{array}{l}\lambda_{\max } \text { of chemically } \\
\text { opened form (nm) }\end{array}$ & $\begin{array}{c}\varepsilon \text { (open form, } \\
\mathrm{mM}^{-1} \mathrm{~cm}^{-1} \text { ) }\end{array}$ \\
\hline \multirow{5}{*}{1} & \multirow{5}{*}{ trans-6a } & 204 & 44.2 & \multirow{5}{*}{$\begin{array}{l}395 \\
490\end{array}$} & \multirow{5}{*}{$\begin{array}{c}4.5 \\
15.4\end{array}$} \\
\hline & & 226 & 30.0 & & \\
\hline & & 253 & 20.8 & & \\
\hline & & 284 & 17.5 & & \\
\hline & & 370 & 8.4 & & \\
\hline \multirow{5}{*}{2} & \multirow{5}{*}{$c i s-7 \mathbf{a}$} & 230 & 22.4 & \multirow{5}{*}{$\begin{array}{l}410 \\
507\end{array}$} & \multirow{5}{*}{$\begin{array}{c}12.7 \\
4.7\end{array}$} \\
\hline & & 260 & 15.0 & & \\
\hline & & 280 & 18.2 & & \\
\hline & & 345 & 8.2 & & \\
\hline & & 370 & 8.1 & & \\
\hline \multirow{5}{*}{3} & \multirow{5}{*}{$\operatorname{trans}-\mathbf{6 b}$} & 205 & 42.9 & \multirow{5}{*}{$\begin{array}{l}393 \\
500\end{array}$} & \multirow{5}{*}{$\begin{array}{l}5.05 \\
19.2\end{array}$} \\
\hline & & 225 & 34.0 & & \\
\hline & & 250 & 24.2 & & \\
\hline & & 283 & 20.0 & & \\
\hline & & 370 & 9.8 & & \\
\hline \multirow{5}{*}{4} & \multirow{5}{*}{ trans $-\mathbf{6 c}$} & 205 & 37.5 & \multirow{5}{*}{$\begin{array}{l}395 \\
500\end{array}$} & \multirow{5}{*}{$\begin{array}{c}4.3 \\
17.7\end{array}$} \\
\hline & & 225 & 31.5 & & \\
\hline & & 250 & 22.3 & & \\
\hline & & 282 & 18.8 & & \\
\hline & & 370 & 9.1 & & \\
\hline \multirow{5}{*}{5} & \multirow{5}{*}{ trans-6d } & 207 & 32.1 & \multirow{5}{*}{$\begin{array}{l}390 \\
505\end{array}$} & \multirow{5}{*}{$\begin{array}{c}3.6 \\
15.3\end{array}$} \\
\hline & & 225 & 27.3 & & \\
\hline & & 253 & 19.3 & & \\
\hline & & 283 & 15.0 & & \\
\hline & & 370 & 8.1 & & \\
\hline
\end{tabular}




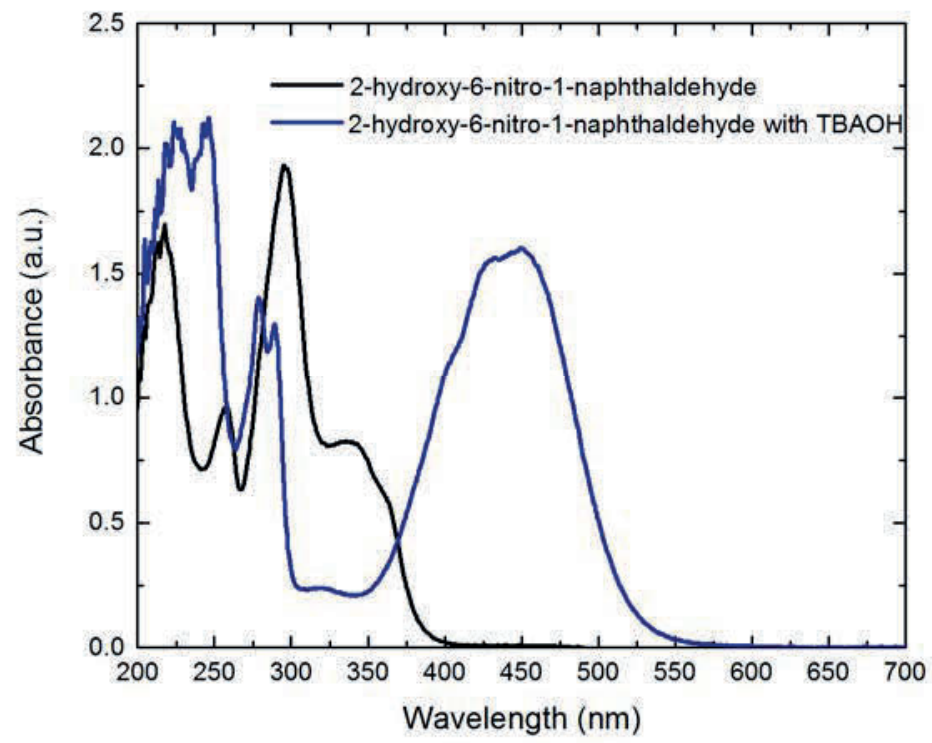

Figure 4. UV-Vis spectra of various forms of 2-hydroxy-6-nitro-1-naphthaldehyde in acetonitrile (black: in pure acetonitrile, blue: after addition of TBAOH).

Table 2. Summary of photochromic parameters of the investigated compounds

\begin{tabular}{|c|c|c|c|c|}
\hline Entry & Compound & $\begin{array}{c}\lambda_{\max } \text { of the } \\
\text { photoinduced form } \\
(\mathrm{nm})\end{array}$ & $\begin{array}{l}\text { Quantum } \\
\text { yield, } \Phi \\
(\%)\end{array}$ & $\begin{array}{c}\text { Relaxation time } \\
\tau(\mathrm{ns})\end{array}$ \\
\hline 1 & trans-6a & $\begin{array}{l}445 \\
515 \text { (shoulder) }\end{array}$ & 3.8 & $26 ; 290$ \\
\hline 2 & $c i s-7 \mathbf{a}$ & $\begin{array}{l}440 \text { (shoulder) } \\
535\end{array}$ & 4.5 & $27 ; 86$ \\
\hline 3 & trans $-\mathbf{6 b}$ & $\begin{array}{l}450 \\
510 \text { (shoulder) }\end{array}$ & 6.5 & $10 ; 65 ; 1090$ \\
\hline 4 & trans-6c & $\begin{array}{l}440 \\
505 \text { (shoulder) }\end{array}$ & 8.1 & $17 ; 140$ \\
\hline 5 & trans-6d & $\begin{array}{l}440 \\
500 \text { (shoulder) }\end{array}$ & 6.4 & $8 ; 124$ \\
\hline
\end{tabular}

It is known that the treatment of 7a,15-methanonaphtho[ $\left[1^{\prime}, 2^{\prime}: 6,7\right][1,3]$ oxazepino[3,2- $a$ ]indole derivatives with strong protic acids, such as perchloric or tetrafluoroboric acid, results in heterolytic cleavage of the $\mathrm{C}-\mathrm{O}$ bond to yield pyrrolo[1,2- $a$ ]indolium salts. ${ }^{16}$ The ${ }^{13} \mathrm{C}$ NMR spectrum of compound trans-6a, registered in TFA- $d$, revealed signals that indicated the cleavage of the bicyclic ring system and the formation of the cation 9 (Scheme 4). Thus, a signal 
at 204.5 ppm was unambiguously assigned to the carbon of the $\mathrm{C}=\mathrm{N}^{+}$group, while the signals of the remaining three carbon atoms of the pyrrolium ring were observed at $35.5\left(\mathrm{CH}_{2}\right), 43.1(\mathrm{CH})$ and $71.1(\mathrm{CH}) \mathrm{ppm}$. When a large excess of TFA was added to a solution of trans-6a in acetonitrile,the UV-Vis spectrum revealed an absorption maximum at $335 \mathrm{~nm}$ (Figure 3, red curve), which was blue-shifted approximately $10 \mathrm{~nm}$ compared to the absorption maximum of trans-6a in pure acetonitrile and can be attributed to the 6-nitro-2-naphthol chromophore of the ring-open form 9. The transient absorption spectra of compounds trans-6a-d and cis-7a in acetonitrile were recorded in the nanosecond domain after UV-laser excitation and in all cases revealed absorption bands situated in the visible region of the electromagnetic spectrum (Table 2). As representative examples, the corresponding transient absorption spectra recorded for trans-6a and cis-7a are shown in Figures 5 and 6. In the case of compound trans-6a, the transient absorption band maximum was located at 440, with a shoulder at $505 \mathrm{~nm}$, while in the case of compound cis-7a, the maximum was at $535 \mathrm{~nm}$, with a shoulder at $440 \mathrm{~nm}$. In both cases, the presence of absorption maxima in the visible region of the electromagnetic spectrum can presumably be attributed to the formation of zwitterionic forms $\mathbf{1 0}$ and 11, incorporating the 6nitro-2-naphtholate chromophore (Scheme 5).
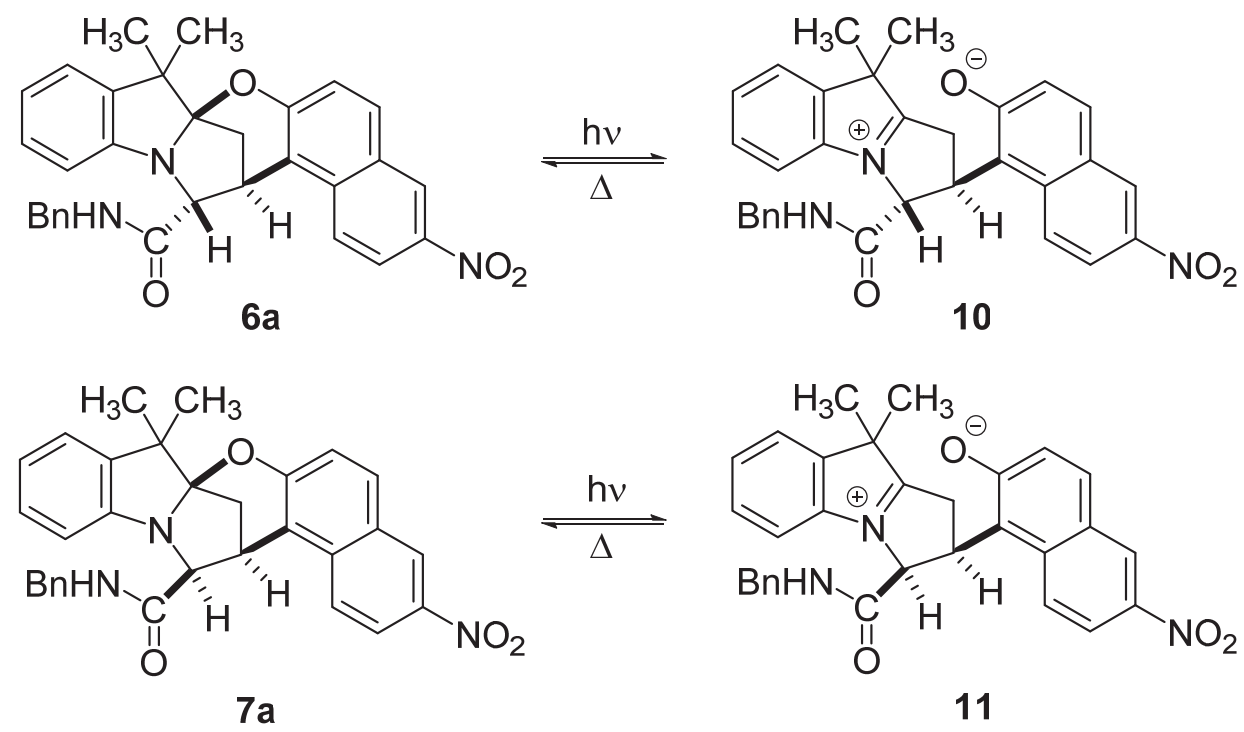

Scheme 5. Photoinduced transformation of trans-6a and cis-7a to the coloured zwitterionic isomers 10 and 11. 


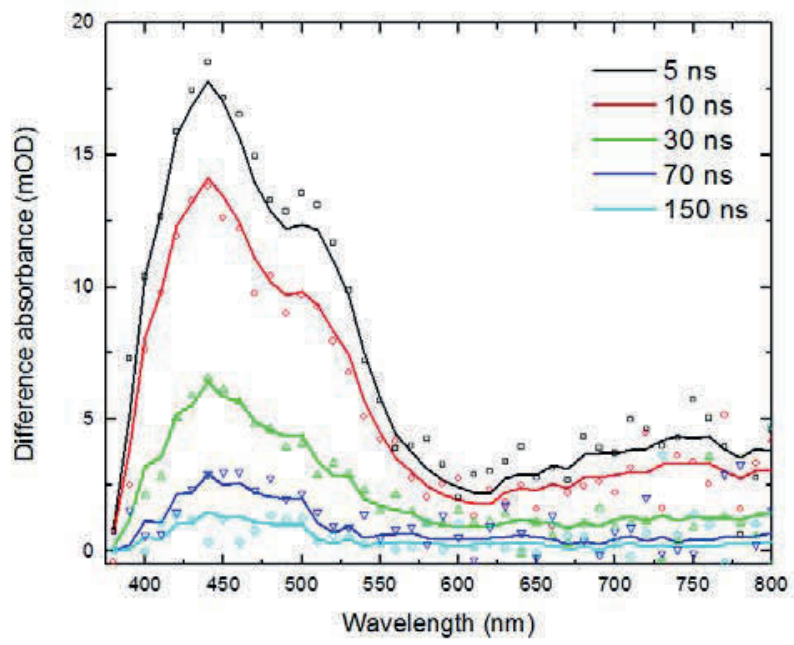

Figure 5. Transient absorption spectra $\left(0.075 \mathrm{mM}\right.$, acetonitrile, $\left.20^{\circ} \mathrm{C}\right)$ of trans-6a recorded on a nanosecond scale after laser excitation $(355 \mathrm{~nm}, 3.5 \mathrm{~mJ})$.

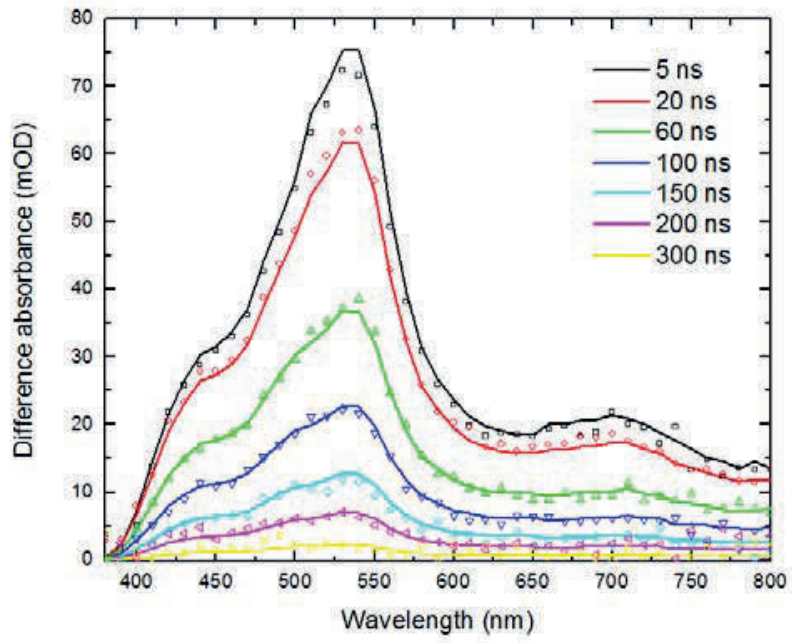

Figure 6. Transient absorption spectra $\left(0.08 \mathrm{mM}\right.$, acetonitrile, $\left.20{ }^{\circ} \mathrm{C}\right)$ of cis-7a recorded on a nanosecond scale after laser excitation $(355 \mathrm{~nm}, 3.5 \mathrm{~mJ})$.

Kinetic traces monitored at a variety of wavelengths (Figure 7) indicated that the coloured species were formed during the excitation pulse (ca. $6 \mathrm{~ns}$ ). In all instances, the induced absorbance decays to zero as the ring-opened isomers trans-10 and cis-11 revert via thermal pathways to the original compounds trans-6a and cis-7a. Relaxation times, estimated from global fitting of the transient data (Table 2), revealed that the thermal reversion of trans-10 and cis-11 to the original form is fast and proceeds in nanosecond time scale. Similar results were obtained in the case of flash photolysis of compounds trans-6b-d. 


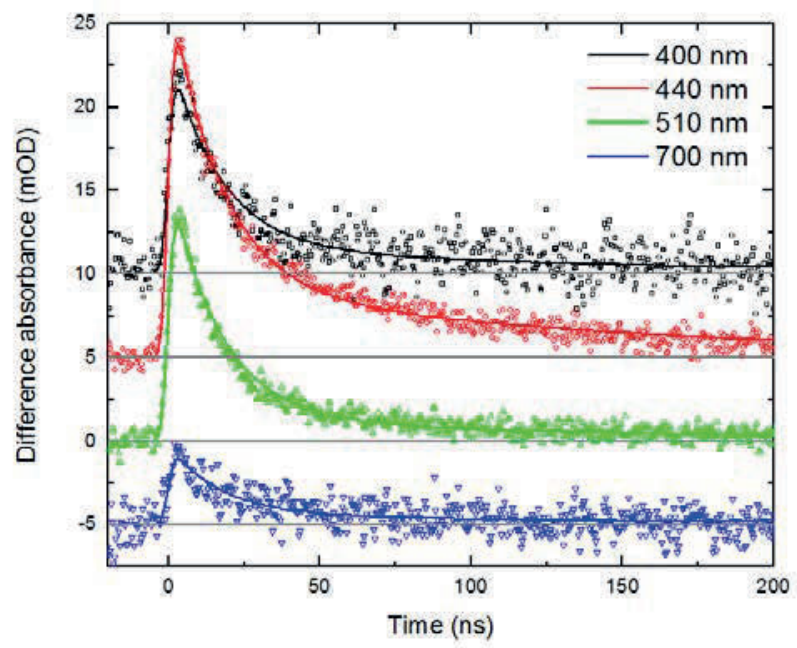

Figure 7. Transient absorption kinetics of $0.075 \mathrm{mM}$ trans-6a in acetonitrile pumped with 355-nm light and probed at selected wavelengths.

The quantum yields of the photochromic reactions were estimated using the molar extinction coefficients of the TBAOH-induced ring-opened forms (Table 1) obtained from the steady state absorption spectra measurements, as described elsewhere. ${ }^{18}$ The corresponding quantum yields of the investigated photochemical reactions were estimated to be ca. 3.8-8.1\% (Table 2).

\section{Conclusions}

New 7a,15-methanonaphtho[ $\left[1^{\prime}, 2^{\prime}: 6,7\right][1,3]$ oxazepino[3,2-a]indole derivatives bearing an 8-nitro group were synthesised by the intramolecular cyclisation of 1'-carbamoylmethyl-8nitrospiro[benzo[f]chromene-3,2'-indole] derivatives upon treatment with a strong base. The relative trans/cis-configuration of the prepared bridged compounds was established by means of ${ }^{1} \mathrm{H}$ NMR spectroscopy and confirmed by single-crystal X-ray analysis. Their steady-state spectra in acetonitrile exhibited the main absorption band at approximately $370 \mathrm{~nm}$, which is characteristic of the 6-nitro-2-naphthoxy chromophore. The addition of TBAOH to a solution of the aforementioned compounds in acetonitrile led to the ring-opening of the bridged system and generation of the 6-nitro-2-naphtholate chromophore with a $\lambda_{\max }$ of approximately $500 \mathrm{~nm}$. UV laser excitation of the uncoloured molecules of trans- and cis-8-nitro-7a,15methanonaphtho[1',2':6,7][1,3] oxazepino[3,2-a]indole induces the formation of short-lived photogenerated species, presumably zwitterionic compounds, which absorb in the visible spectrum and thermally revert to the ground state on a nanosecond time scale. 


\section{Experimental Section}

General. Reagents and solvents were purchased from Sigma-Aldrich and used without further purification. Reactions were monitored by TLC analysis on precoated silica gel plates (Kieselgel $60 \mathrm{~F}_{254}$, Merck). Compounds were visualised with UV light or by treatment with iodine vapour. Column chromatography was performed on silica gel SI 60 (43-60 $\mu \mathrm{m}$, E. Merck). Melting points were determined in open capillary tubes with a Büchi B-540 melting point apparatus. Infrared spectra were recorded on a Perkin Elmer Spectrum One spectrometer using potassium bromide pellets. ${ }^{1} \mathrm{H}$ NMR spectra were recorded at $300 \mathrm{MHz}$ on a Varian Unity Inova spectrometer, at $400 \mathrm{MHz}$ on a Bruker Avance III spectrometer. ${ }^{13} \mathrm{C}$ NMR spectra were collected using the same instruments at 75, 100 and $175 \mathrm{MHz}$. The chemical shifts are expressed in ppm downfield relative to TMS, and the coupling constants $(J)$, referring to apparent peak multiplicity, are reported in Hz. Diffraction data were collected on a Bruker-Nonius KappaCCD diffractometer at room temperature and at $-100{ }^{\circ} \mathrm{C}$. The crystal structures were solved using known programs. ${ }^{35}$ Elemental analyses were measured with a CE-440 elemental analyzer, Model $440 \mathrm{CHN} / \mathrm{O} / \mathrm{S}$. Low-resolution mass spectra were recorded via direct injection on a Waters Micromass ZQ 2000 mass spectrometer applying positive atmospheric pressure chemical ionization $\left(\mathrm{APCI}^{+}, 20 \mathrm{~V}\right)$. High-resolution ESI-TOF mass spectra were measured on a Bruker maXis spectrometer. Steady state absorption spectra of the solutions were measured using a Shimadzu scanning spectrophotometer model UV-3101PC.

Flash photolysis experiments were performed using a nanosecond Q-switched Nd:YAG laser (EKSPLA NL301), and pulses of the third harmonic (wavelength $-355 \mathrm{~nm}$, duration $-6 \mathrm{~ns}$ ) were applied for excitation. ${ }^{19}$ The energy of the pulses for flash photolysis was approximately $3.5 \mathrm{~mJ}$. Sample transmission was probed using light flashes with a duration of $\sim 100 \mu$ s generated by a laser-synchronised Xe lamp covering the spectral range of 380-850 nm. Temporal changes in the sample transmission were detected by two high-speed photodiodes (Thorlabs DET10A) placed behind two monochromators for the sample and reference beams. The signals were recorded using a $1 \mathrm{GHz}$ bandwidth oscilloscope (Tektronix TDS7104). All nanosecond kinetic traces presented here were obtained by averaging at least 30 experimental measurements. To avoid local over-exposure of the sample, solutions were mixed with a home-built magnetic stirrer. IRF of the experiments was approximately $6 \mathrm{~ns}$.

Nanosecond-resolution flash-photolysis experimental data were analysed using global analysis techniques described elsewhere. ${ }^{36}$ All the flash-photolysis data presented here were fitted using a linear evolution model with the smallest number of compartments necessary to provide a satisfactory fit. One or two kinetic components were adequate to describe the data presented herein.

The quantum yields of photochromic transformations were determined following the calibration method described elsewhere. ${ }^{18}$ Briefly, benzophenone was used as a standard with its intersystem crossing quantum yield assumed to be unity. The quantum yield of the photoinduced ring opening was determined with Equation 1: 


$$
\Phi=\frac{\chi \varepsilon_{b z P} \Phi_{b z P}}{\chi_{b z P} \varepsilon}
$$

The terms $\chi$ and $\chi_{b z P}$ are the slopes of linear portions of the plots of the maximum amplitude of induced absorption measured at $\lambda_{\max }$ against the pump pulse energy $\left(A=f\left(E_{\text {laser }}\right)\right)$ of the ringopened compound and benzophenone, respectively. The molar extinction coefficients $\varepsilon$ of the investigated compounds were determined by chemically inducing the opening of the ring with TBAOH; $\varepsilon_{b z P}$ for its triplet absorption at $520 \mathrm{~nm}$ is $6.5 \mathrm{mM}^{-1} \mathrm{~cm}^{-1} .^{37}$

1,7,9,9,9a-Pentamethyl-9,9a-dihydro-1 $H$-imidazo[1,2-a]indol-2(3H)-one (4d). 7,9,9,9a-Tetramethyl-9,9a-dihydro-1H-imidazo[1,2- $a$ ]indol-2(3H)-one (3b) (2.61 g, $11.3 \mathrm{mmol})$ was dissolved in $25 \mathrm{ml} \mathrm{DMF}$ and finely powdered $\mathrm{KOH}(0.95 \mathrm{~g}, 16.95 \mathrm{mmol})$ was added. Iodomethane $(4.81 \mathrm{~g}$, $2.1 \mathrm{ml}, 33.9 \mathrm{mmol}$ ) was added dropwise to the solution and the mixture was stirred for $2 \mathrm{~h}$ at $\mathrm{rt}$. Then the reaction mixture was poured into water $(100 \mathrm{ml})$ and extracted with ether $(3 \times 50 \mathrm{ml})$. The combined organic layer was dried over anhydrous $\mathrm{Na}_{2} \mathrm{SO}_{4}$, concentrated in vacuo and the residue was subjected to flash chromatography on silica gel (hexane/acetone 3:1) to yield the title compound 4d. Yellowish oil, yield $1.99 \mathrm{~g}(72 \%)$. IR: $v_{\max } 3035,2968,1704 \mathrm{~cm}^{-1}(\mathrm{C}=\mathrm{O}) .{ }^{1} \mathrm{H}$ NMR (400 MHz, CDCl $\left.)_{3}\right): \delta_{\mathrm{H}} 1.15\left(3 \mathrm{H}, \mathrm{s}, \mathrm{CH}_{3}\right), 1.38\left(3 \mathrm{H}, \mathrm{s}, \mathrm{CH}_{3}\right), 1.46\left(3 \mathrm{H}, \mathrm{s}, \mathrm{CH}_{3}\right), 2.29(3 \mathrm{H}$, s, $\left.\mathrm{CH}_{3}\right), 2.93\left(3 \mathrm{H}, \mathrm{s}, \mathrm{CH}_{3}\right), 3.74(1 \mathrm{H}, \mathrm{AB}-\mathrm{d}, J 15.6 \mathrm{~Hz}, \mathrm{CH}), 4.00\left(1 \mathrm{H}, \mathrm{AB}-\mathrm{d}, J 15.6 \mathrm{~Hz}, \mathrm{CHH}^{\prime}\right)$, $6.67(1 \mathrm{H}, \mathrm{d}, J 8.0 \mathrm{~Hz}, 5-\mathrm{H}), 6.83(1 \mathrm{H}, \mathrm{d}, J 0.4 \mathrm{~Hz}, 8-\mathrm{H}), 6.97(1 \mathrm{H}, \mathrm{dd}, J 8.0,0.4 \mathrm{~Hz}, 6-\mathrm{H}) .{ }^{13} \mathrm{C}$ NMR (100 MHz, $\left.\mathrm{CDCl}_{3}\right): \delta_{\mathrm{C}} 21.2\left(\mathrm{CH}_{3}\right), 21.8\left(\mathrm{CH}_{3}\right), 24.2\left(\mathrm{CH}_{3}\right), 28.0\left(\mathrm{CH}_{3}\right), 28.3\left(\mathrm{CH}_{3}\right), 49.5$ (C-9), $55.0\left(\mathrm{CH}_{2}\right), 92.6(\mathrm{C}-9 \mathrm{a}), 113.7(\mathrm{CH}), 122.9(\mathrm{CH}), 128.9(\mathrm{CH}), 131.9(\mathrm{C}), 140.8(\mathrm{C}), 146.7$ (C), $171.9(\mathrm{C}=\mathrm{O})$. HRMS (ESI TOF): $[\mathrm{M}+\mathrm{H}]^{+}$, found 245.1650, $\left[\mathrm{C}_{15} \mathrm{H}_{20} \mathrm{~N}_{2} \mathrm{O}+\mathrm{H}\right]^{+}$requires 245.1648 .

\section{$\boldsymbol{N}$-Benzyl-2-(3',3'-dimethyl-8-nitrospiro[benzo[f]chromene-3,2'-indol]-1'(3' $H)$-yl)acetamide} (5a). A mixture of imidazo[1,2-a]indol-2-one $4 \mathbf{a}(500 \mathrm{mg}, 1.63 \mathrm{mmol})$ and 2-hydroxy-6-nitronaphthaldehyde $(355 \mathrm{mg}, 1.63 \mathrm{mmol})$ in acetic acid $(7 \mathrm{ml})$ was heated at $100{ }^{\circ} \mathrm{C}$ for $2 \mathrm{~h}$. Then the reaction mixture was poured into aqueous $5 \%$ sodium acetate solution $(50 \mathrm{ml})$, diethyl ether $(15$ $\mathrm{ml}$ ) was poured on the top and the mixture was stored at $5{ }^{\circ} \mathrm{C}$ for $16 \mathrm{~h}$. The precipitated crystalline material was filtered, washed with cold ethanol $(1 \mathrm{ml})$ and recrystallized from acetonitrile to give 5a. Yellowish crystals, yield $665 \mathrm{mg}$ (81\%), mp 121-122 ${ }^{\circ} \mathrm{C}$ (from acetonitrile). IR: $v_{\max } 3410(\mathrm{~N}-\mathrm{H}), 3031,2989,1679 \mathrm{~cm}^{-1}(\mathrm{C}=\mathrm{O}) .{ }^{1} \mathrm{H}$ NMR $\left(300 \mathrm{MHz}, \mathrm{CDCl}_{3}\right)$ : $\delta_{\mathrm{H}} 1.23\left(3 \mathrm{H}, \mathrm{s}, \mathrm{CH}_{3}\right), 1.34\left(3 \mathrm{H}, \mathrm{s}, \mathrm{CH}_{3}\right), 3.85\left(1 \mathrm{H}, \mathrm{AB}-\mathrm{d}, J 18.0 \mathrm{~Hz}, \mathrm{CHH}^{\prime}\right), 4.03(1 \mathrm{H}, \mathrm{AB}-\mathrm{d}, J$ $\left.18.0 \mathrm{~Hz}, \mathrm{CHH}^{\prime}\right), 4.45\left(2 \mathrm{H}, \mathrm{d}, J 5.7 \mathrm{~Hz}, \mathrm{NHCH}_{2}\right), 5.82(1 \mathrm{H}, \mathrm{d}, J 10.5 \mathrm{~Hz}, \mathrm{CH}=\mathrm{CH}), 6.57(1 \mathrm{H}, \mathrm{d}, J$ $7.5 \mathrm{~Hz}, 7-\mathrm{H}), 6.89\left(1 \mathrm{H}, \mathrm{d}, J 9.0 \mathrm{~Hz}, 5^{\prime}-\mathrm{H}\right), 6.95-7.01$ (2H, m, Ar-H), 7.14-7.29 (7H, m, Ar-H), $7.59(1 \mathrm{H}, \mathrm{d}, J 10.5 \mathrm{~Hz}, \mathrm{CH}=\mathrm{CH}), 7.75\left(1 \mathrm{H}, \mathrm{d}, J 9.0 \mathrm{~Hz}, 6^{\prime}-\mathrm{H}\right), 8.08\left(1 \mathrm{H}, \mathrm{d}, J 9.0 \mathrm{~Hz}, 10^{\prime}-\mathrm{H}\right), 8.27$ $\left(1 \mathrm{H}, \mathrm{dd}, J 9.0,2.4 \mathrm{~Hz}, 9^{\prime}-\mathrm{H}\right), 8.67\left(1 \mathrm{H}, \mathrm{d}, J 2.4 \mathrm{~Hz}, 7^{\prime}-\mathrm{H}\right) .{ }^{13} \mathrm{C} \mathrm{NMR}\left(75 \mathrm{MHz}, \mathrm{CDCl}_{3}\right): \delta_{\mathrm{C}} 20.2$, 25.8, 43.2, 48.1, 52.3, 105.1 (C-spiro), 107.5, 110.7, 117.9, 119.2, 120.4, 121.1, 122.1, 125.3, $125.4,127.3,127.3(2 \times \mathrm{C}), 127.5,128.0,128.6(2 \times \mathrm{C}), 132.5,132.6,135.9,137.7,143.7$, 145.7, 154.6, 169.7, $176.5(\mathrm{C}=\mathrm{O})$. MS m/z (\%): $506\left(\mathrm{M}+\mathrm{H}^{+}, 100\right)$. Anal. Calcd for $\mathrm{C}_{31} \mathrm{H}_{27} \mathrm{~N}_{3} \mathrm{O}_{4}$ (505.56): C, 73.65; H, 5.38; N, 8.31. Found: C 72.87; H, 5.48; N, 8.19\%. 
2-(3',3'-Dimethyl-8-nitrospiro[benzo[f]chromene-3,2'-indol]-1'(3'H)-yl)- $\mathrm{N}$-(prop-2-en-1-yl)acetamide (5b). Following the preparation of 5a, the condensation of imidazo[1,2- $a$ ]indol-2-one 4b (2.5 g, $9.75 \mathrm{mmol})$ with 2-hydroxy-6-nitro-naphthaldehyde (2.12 g, $9.75 \mathrm{mmol})$ in glacial acetic acid $(7 \mathrm{ml})$ and standard workup gave the title compound $\mathbf{5 b}$. Yellowish crystals, yield $1.34 \mathrm{~g}(29 \%), \mathrm{mp} 161-162{ }^{\circ} \mathrm{C}$ (from acetonitrile). IR: $v_{\max } 3423(\mathrm{~N}-\mathrm{H}), 3062,2966,1641 \mathrm{~cm}^{-1}$ $(\mathrm{C}=\mathrm{O}) .{ }^{1} \mathrm{H}$ NMR $\left(400 \mathrm{MHz}, \mathrm{CDCl}_{3}\right): \delta_{\mathrm{H}} 1.29\left(3 \mathrm{H}, \mathrm{s}, \mathrm{CH}_{3}\right), 1.38\left(3 \mathrm{H}, \mathrm{s}, \mathrm{CH}_{3}\right), 3.75(1 \mathrm{H}, \mathrm{AB}-\mathrm{d}, J$ $\left.17.6 \mathrm{~Hz}, \mathrm{CHH}^{\prime}\right), 3.87-3.91\left(2 \mathrm{H}, \mathrm{m}, \mathrm{CH}_{2}\right), 3.97$ (1H, AB-d, J 17.6 Hz, CHH'), 5.06-5.10 (2H, m, $\left.\mathrm{CH}_{2}\right), 5.72-5.82(1 \mathrm{H}, \mathrm{m}, \mathrm{CH}), 5.88(1 \mathrm{H}, \mathrm{d}, J 10.4 \mathrm{~Hz}, \mathrm{CH}=\mathrm{CH}), 6.55(1 \mathrm{H}, \mathrm{d}, J 7.2 \mathrm{~Hz}, 4-\mathrm{H}), 6.65$ $(1 \mathrm{H}, \mathrm{t}, J 5.6 \mathrm{~Hz}, \mathrm{CONH}), 7.00(1 \mathrm{H}, \mathrm{t}, J 7.2 \mathrm{~Hz}, 5-\mathrm{H}), 7.08\left(1 \mathrm{H}, \mathrm{d}, J 9.2 \mathrm{~Hz}, 6^{6}-\mathrm{H}\right), 7.18(1 \mathrm{H}, \mathrm{d}, J$ $7.2 \mathrm{~Hz}, 7-\mathrm{H}), 7.23(1 \mathrm{H}, \mathrm{dt}, J 7.2,0.8 \mathrm{~Hz}, 6-\mathrm{H}), 7.61(1 \mathrm{H}, \mathrm{d}, J 10.4 \mathrm{~Hz}, \mathrm{CH}=\mathrm{CH}), 7.82(1 \mathrm{H}, \mathrm{d}, J$ $\left.9.0 \mathrm{~Hz}, 5^{`}-\mathrm{H}\right), 8.08(1 \mathrm{H}, \mathrm{d}, J 9.0 \mathrm{~Hz}, 10-\mathrm{H}), 8.27\left(1 \mathrm{H}, \mathrm{dd}, J 9.0,2.4 \mathrm{~Hz}, 9^{`}-\mathrm{H}\right), 8.69$ (1H, d, J 2.4 $\mathrm{Hz}, 7$ - $-\mathrm{H}) .{ }^{13} \mathrm{C} \mathrm{NMR}\left(100 \mathrm{MHz}, \mathrm{CDCl}_{3}\right): \delta_{\mathrm{C}} 20.4,26.1,31.1,41.6,48.4,52.3,105.2$ (C-spiro), $107.8,110.9,116.4,118.0,119.5,120.6,121.3,122.2,125.5,125.6,127.5,128.2,132.7,132.8$, 133.9, 136.25, 143.9, 145.9, 154.9, $169.4(\mathrm{C}=\mathrm{O})$. HRMS (ESI TOF): $[\mathrm{M}+\mathrm{H}]^{+}$, found 456.1917; $\left[\mathrm{C}_{27} \mathrm{H}_{25} \mathrm{~N}_{3} \mathrm{O}_{4}+\mathrm{H}\right]^{+}$requires 456.1918 .

2-(3',3'-Dimethyl-8-nitrospiro[benzo[ $f$ ]chromene-3,2'-indol]-1'(3' $H)$-yl)- $N$-methylacetamide $(\mathbf{5 c})$. Following the preparation of $\mathbf{5 a}$, the condensation of imidazo[1,2-a]indol-2-one $\mathbf{4 c}(1.86 \mathrm{~g}$, $8.0 \mathrm{mmol})$ and 2-hydroxy-6-nitronaphthaldehyde $(1.75 \mathrm{~g}, 8.0 \mathrm{mmol})$ in glacial acetic acid (15 $\mathrm{ml}$ ) and workup gave the title compound 5c. Yellowish crystals, yield $1.61 \mathrm{~g}(46 \%), \mathrm{mp} 170-172$ ${ }^{\circ} \mathrm{C}$ (from acetonitrile). IR: $v_{\max } 3417(\mathrm{~N}-\mathrm{H}), 3076,2963,1644 \mathrm{~cm}^{-1}(\mathrm{C}=\mathrm{O}) .{ }^{1} \mathrm{H}$ NMR $(300 \mathrm{MHz}$, $\left.\mathrm{CDCl}_{3}\right): \delta_{\mathrm{H}} 1.31\left(3 \mathrm{H}, \mathrm{s}, \mathrm{CH}_{3}\right), 1.37\left(3 \mathrm{H}, \mathrm{s}, \mathrm{CH}_{3}\right), 2.80\left(3 \mathrm{H}, \mathrm{d}, J 5.1 \mathrm{~Hz}, \mathrm{CH}_{3}\right), 3.69(1 \mathrm{H}, \mathrm{AB}-\mathrm{d}, J$ $\left.18.0 \mathrm{~Hz}, \mathrm{CHH}^{\prime}\right), 3.94\left(1 \mathrm{H}, \mathrm{AB}-\mathrm{d}, J 18.0 \mathrm{~Hz}, \mathrm{CHH}^{\prime}\right), 5.88(1 \mathrm{H}, \mathrm{d}, J 10.5 \mathrm{~Hz}, \mathrm{CH}=\mathrm{CH}), 6.51-6.57$ $(1 \mathrm{H}, \mathrm{m}, \mathrm{CONH}), 6.52(1 \mathrm{H}, \mathrm{d}, J 7.5 \mathrm{~Hz}, 7-\mathrm{H}), 6.99(1 \mathrm{H}, \mathrm{dt}, J 7.5,1.2 \mathrm{~Hz}, 5-\mathrm{H}), 7.08(\mathrm{~d}, J 9.0 \mathrm{~Hz}$, $\left.1 \mathrm{H}, 5^{\prime}-\mathrm{H}\right), 7.18(\mathrm{~d}, J 6.3 \mathrm{~Hz}, 1 \mathrm{H}, 4-\mathrm{H}), 7.22$ (dt, J 7.5, $\left.1.2 \mathrm{~Hz}, 1 \mathrm{H}, 6-\mathrm{H}\right), 7.60(1 \mathrm{H}, \mathrm{d}, J 10.5 \mathrm{~Hz}$, $\mathrm{CH}=\mathrm{CH}), 7.82\left(1 \mathrm{H}, \mathrm{d}, J 9.0 \mathrm{~Hz}, 6^{\prime}-\mathrm{H}\right), 8.07\left(1 \mathrm{H}, \mathrm{d}, J 9.0 \mathrm{~Hz}, 10^{\prime}-\mathrm{H}\right), 8.26(1 \mathrm{H}, \mathrm{dd}, J 9.0,2.4 \mathrm{~Hz}$, $\left.9^{\prime}-\mathrm{H}\right), 8.68\left(1 \mathrm{H}, \mathrm{d}, J 2.4 \mathrm{~Hz}, 7^{\prime}-\mathrm{H}\right) .{ }^{13} \mathrm{C} \mathrm{NMR}\left(75 \mathrm{MHz}, \mathrm{CDCl}_{3}\right): \delta_{\mathrm{C}} 20.2,26.0,26.1,48.2,52.1$, 105.0 (C-spiro), 107.7, 110.7, 117.8, 119.3, 120.4, 121.2, 122.1, 125.3, 125.4, 127.3, 128.0, 132.5, $132.6136 .1,139.9,143.7,145.9,154.7,170.0(\mathrm{C}=\mathrm{O})$. MS m/z $(\%): 430\left(\mathrm{M}+\mathrm{H}^{+}, 100\right)$. Anal. Calcd for $\mathrm{C}_{25} \mathrm{H}_{23} \mathrm{~N}_{3} \mathrm{O}_{4}$ (429.47): C, 69.92; H, 5.40; N, 9.78. Found: C, 69.65; H, 5.55; N, $9.82 \%$.

$\mathrm{N}$-Methyl-2-(3',3',5'-trimethyl-8-nitrospiro[benzo[f]chromene-3,2'-indol]-1'(3'H)-yl)acetamide (5d). Following the preparation of 5a, the condensation of imidazo[1,2-a]indol-2-one 4d (1.9 g, $7.78 \mathrm{mmol})$ with 2-hydroxy-6-nitronaphthaldehyde (1.69 g, $7.78 \mathrm{mmol})$ in acetic acid (7 $\mathrm{ml})$ and workup gave the title compound 5d. Colourless crystals, yield $1.95 \mathrm{~g}(57 \%)$, mp 225$226{ }^{\circ} \mathrm{C}$ (from acetonitrile). IR: $v_{\max } 3374(\mathrm{~N}-\mathrm{H}), 3054,2971,1658 \mathrm{~cm}^{-1}(\mathrm{C}=\mathrm{O}) .{ }^{1} \mathrm{H}$ NMR $(300$ $\left.\mathrm{MHz}, \mathrm{CDCl}_{3}\right): \delta_{\mathrm{H}} 1.30\left(3 \mathrm{H}, \mathrm{s}, \mathrm{CH}_{3}\right), 1.36\left(3 \mathrm{H}, \mathrm{s}, \mathrm{CH}_{3}\right), 2.36\left(3 \mathrm{H}, \mathrm{s}, 5-\mathrm{CH}_{3}\right), 2.80(3 \mathrm{H}, \mathrm{d}, J 4.8$ $\left.\mathrm{Hz}, \mathrm{NH}-\mathrm{CH}_{3}\right), 3.64\left(1 \mathrm{H}, \mathrm{AB}-\mathrm{d}, J 18.0 \mathrm{~Hz}, \mathrm{CHH}^{\prime}\right), 3.90\left(1 \mathrm{H}, \mathrm{AB}-\mathrm{d}, J 18.0 \mathrm{~Hz}, \mathrm{CHH}^{\prime}\right), 5.88(1 \mathrm{H}$, d, $J 10.5 \mathrm{~Hz}, \mathrm{CH}=\mathrm{CH}), 6.42(1 \mathrm{H}, \mathrm{d}, J 7.8 \mathrm{~Hz}, \mathrm{Ar}-\mathrm{H}), 6.52-6.56(1 \mathrm{H}, \mathrm{m}, \mathrm{CONH}), 7.00-7.04(2 \mathrm{H}$, m, Ar-H), 7.09 (1H, d, J 9.0 Hz, 5'-H), $7.59(1 \mathrm{H}, \mathrm{d}, J 10.5 \mathrm{~Hz}, \mathrm{CH}=\mathrm{CH}), 7.82(1 \mathrm{H}, \mathrm{d}, J 9.0 \mathrm{~Hz}$, 6'-H), 8.07 (1H, d, J 9.0 Hz, 10'-H), 8.26 (1H, dd, J 9.0, 2.4 Hz, 9'-H), 8,68 (1H, d, J 2.4 Hz, 7'- 
H). ${ }^{13} \mathrm{C}$ NMR $\left(75 \mathrm{MHz}, \mathrm{CDCl}_{3}\right): \delta_{\mathrm{C}} 20.3,21.2,26.2,26.3,48.5,52.2,105.3$ (C-spiro), 107.7, $110.9,118.0,119.5,120.6,122.2,123.1,125.5,125.5,127.4,128.4,130.9,132.7,136.5,143.8$, 143.9, 155.0, $170.3(\mathrm{C}=\mathrm{O})$. Anal. Calcd for $\mathrm{C}_{26} \mathrm{H}_{25} \mathrm{~N}_{3} \mathrm{O}_{4}$ (443.49): C, 70.41; H, 5.68; N, 9.47. Found: C, 70.81; H, 5.84; N, $9.37 \%$. HRMS (ESI TOF): $[\mathrm{M}+\mathrm{H}]^{+}$, found 444.1921. $\left[\mathrm{C}_{26} \mathrm{H}_{25} \mathrm{~N}_{3} \mathrm{O}_{4}+\mathrm{H}\right]^{+}$requires 444.1918 .

$\left(7 \mathrm{a} R^{*}, 14 R^{*}, 15 S^{*}\right)-$ and $\left(7 \mathrm{a} R^{*}, 14 S^{*}, 15 S^{*}\right)-N$-Benzyl-8,8-dimethyl-3-nitro-14,15-dihydro-8H7a,15-methanonaphtho $\left[1^{\prime}, 2^{\prime}: 6,7\right][1,3]$ oxazepino $[3,2-a]$ indole-14-carboxamides (trans-6a and cis-7a). To a solution of $\mathbf{5 a}(500 \mathrm{mg}, 0.99 \mathrm{mmol})$ in ethanol $(20 \mathrm{ml})$ finely powdered $\mathrm{KOH}(166$ $\mathrm{mg}, 2.97 \mathrm{mmol}$ ) was added at $\mathrm{rt}$. The reaction mixture was refluxed for $5 \mathrm{~h}$, then allowed to reach $\mathrm{rt}$ and stored at $5{ }^{\circ} \mathrm{C}$ for $16 \mathrm{~h}$. The precipitated crystals of cis-7a were collected by filtration and recrystallized from acetonitrile. The filtrate was poured into water $(30 \mathrm{ml})$, acetic acid was added to the mixture until it became colourless and then diethyl ether $(5 \mathrm{ml})$ was poured on the top. The precipitated crystals were collected by filtration, washed with cold ethanol $(1 \mathrm{ml})$ and recrystallized from ethanol to afford trans-6a.

Isomer trans-6a: yellowish crystals, yield $200 \mathrm{mg}(40 \%), \mathrm{mp} 213-214{ }^{\circ} \mathrm{C}$ (from ethanol). IR: $v_{\max } 3302(\mathrm{~N}-\mathrm{H}), 3028,2968,1666 \mathrm{~cm}^{-1}(\mathrm{C}=\mathrm{O}) .{ }^{1} \mathrm{H}$ NMR $\left(300 \mathrm{MHz}, \mathrm{CDCl}_{3}\right): \delta_{\mathrm{H}} 1.25(3 \mathrm{H}, \mathrm{s}$, $\left.\mathrm{CH}_{3}\right), 1.63\left(3 \mathrm{H}, \mathrm{s}, \mathrm{CH}_{3}\right), 2.16\left(1 \mathrm{H}, \mathrm{d}, J 11.6 \mathrm{~Hz}, \mathrm{CHH}^{\prime}\right), 2.61\left(1 \mathrm{H}, \mathrm{dd}, J 11.6,4.2 \mathrm{~Hz}, \mathrm{CHH}^{\prime}\right)$, $4.34\left(1 \mathrm{H}, \mathrm{dd}, J 14.7,6.0 \mathrm{~Hz}, \mathrm{CHH}^{\prime} \mathrm{Ph}\right), 4.44(1 \mathrm{H}, \mathrm{d}, J 4.2 \mathrm{~Hz}, 15-\mathrm{H}), 4.47$ (1H, s, 14-H), 4.52 $\left(1 \mathrm{H}, \mathrm{dd}, J 14.7,6.0 \mathrm{~Hz}, \mathrm{CHH}^{\prime} \mathrm{Ph}\right), 6.26-6.31(2 \mathrm{H}, \mathrm{m}, \mathrm{Ar}-\mathrm{H}), 6.80(1 \mathrm{H}, \mathrm{t}, J 7.5 \mathrm{~Hz}, \mathrm{Ar}-\mathrm{H}), 6.99-$ $7.15(5 \mathrm{H}, \mathrm{m}, \mathrm{Ar}-\mathrm{H}), 7.26-7.29(3 \mathrm{H}, \mathrm{m}, \mathrm{Ar}-\mathrm{H}), 7.75(1 \mathrm{H}, \mathrm{d}, J 9.0 \mathrm{~Hz}, 5-\mathrm{H}), 8.07(1 \mathrm{H}, \mathrm{d}, J 9.0 \mathrm{~Hz}$, 1-H), $8.19(1 \mathrm{H}, \mathrm{dd}, J 9.0,2.1 \mathrm{~Hz}, 2-\mathrm{H}), 8.63(1 \mathrm{H}, \mathrm{d}, J 2.1 \mathrm{~Hz}, 4-\mathrm{H}) .{ }^{13} \mathrm{C} \mathrm{NMR}\left(75 \mathrm{MHz}, \mathrm{CDCl}_{3}\right)$ : $\delta_{\mathrm{C}} 20.7,27.9,28.2,41.8,43.6,44.7,67.5,107.2,107.9,119.9,120.2,121.1,122.5,122.9,125.4$, $126.9,127.4(2 \times \mathrm{C}), 127.6,127.9,128.7(2 \times \mathrm{C}), 130.9,133.5,137.5,140.9,141.2,141.5,143.2$, 154.5, $169.6(\mathrm{C}=\mathrm{O})$. MS m/z (\%): $506\left(\mathrm{M}+\mathrm{H}^{+}, 100\right)$. Anal. Calcd for $\mathrm{C}_{31} \mathrm{H}_{27} \mathrm{~N}_{3} \mathrm{O}_{4}(505.56): \mathrm{C}$, 73.65; H, 5.38; N, 8.31\%. Found: C, 73.47; H, 5.41; N, 8.28\%.

NMR spectra of compound 6a registered in TFA-d (compound 9): ${ }^{1} \mathrm{H}$ NMR (400 MHz, TFA- $d$ ): $\delta_{\mathrm{H}} 1.77\left(3 \mathrm{H}, \mathrm{s}, \mathrm{CH}_{3}\right), 1.83\left(3 \mathrm{H}, \mathrm{s}, \mathrm{CH}_{3}\right), 3.80(1 \mathrm{H}, \mathrm{dd}, J 21.6,4.8 \mathrm{~Hz}, \mathrm{CH}), 4.05(1 \mathrm{H}, \mathrm{ddd}, J 21.6$, 10.0, $2.8 \mathrm{~Hz}, \mathrm{CH}), 4.42$ (1H, d, J 14.6 Hz, CHH'Ph), 4.72 (1H, d, J 14.6 Hz, CHH'Ph), 5.34-5.39 $(1 \mathrm{H}, \mathrm{m}, \mathrm{CH}), 5.85(1 \mathrm{H}, \mathrm{d}, J 4.8 \mathrm{~Hz}, \mathrm{CH}), 7.21(2 \mathrm{H}, \mathrm{d}, J 7.2 \mathrm{~Hz}, \mathrm{Ar}-\mathrm{H}), 7.30-7.42$ (5H, m, Ar-H), 7.57-7.61 (1H, m, Ar-H), $7.72(2 \mathrm{H}, \mathrm{d}, J 4.0 \mathrm{~Hz}, \mathrm{Ar}-\mathrm{H}), 7.88(1 \mathrm{H}, \mathrm{d}, J 9.6 \mathrm{~Hz}, \mathrm{Ar}-\mathrm{H}), 8.04(1 \mathrm{H} \mathrm{d}$, $J 9.6 \mathrm{~Hz}, \mathrm{Ar}-\mathrm{H}), 8.13$ (1H, dd, J 9.6, $2.4 \mathrm{~Hz}, \mathrm{Ar}-\mathrm{H}), 8.77$ (1H, d, $J 2.4 \mathrm{~Hz}, \mathrm{Ar}-\mathrm{H}) .{ }^{13} \mathrm{C}$ NMR $(100$ MHz, TFA-d $): \delta_{\mathrm{C}} 21.6\left(\mathrm{CH}_{3}\right), 22.4\left(\mathrm{CH}_{3}\right), 35.5\left(\mathrm{CH}_{2}\right), 43.1(\mathrm{CH}), 45.5\left(\mathrm{COCH}_{2}\right), 51.4(\mathrm{C}), 71.1$ $(\mathrm{CH}), 115.5,117.2,120.7,121.7,123.0,124.5,127.1,128.6(2 \times \mathrm{C}), 129.2,129.7(2 \times \mathrm{C}), 130.4$, 131.7, 134.6, 136.1, 136.4, 137.1, 143.8, 146.1, 157.5, $168.6(\mathrm{C}=\mathrm{O}), 204.5\left(\mathrm{C}=\mathrm{N}^{+}\right)$.

Isomer cis-7a: yellowish crystals, yield $100 \mathrm{mg}(20 \%), \mathrm{mp} 233-234{ }^{\circ} \mathrm{C}$ (from acetonitrile). IR $\left(v_{\max }, \mathrm{cm}^{-1}\right): 3362(\mathrm{~N}-\mathrm{H}), 3048,2930,1673(\mathrm{C}=\mathrm{O}) .{ }^{1} \mathrm{H}$ NMR $\left(300 \mathrm{MHz}, \mathrm{CDCl}_{3}\right): \delta_{\mathrm{H}} 1.526(3 \mathrm{H}$, $\left.\mathrm{s}, \mathrm{CH}_{3}\right), 1.533\left(3 \mathrm{H}, \mathrm{s}, \mathrm{CH}_{3}\right), 2.22\left(1 \mathrm{H}, \mathrm{d}, J 11.7 \mathrm{~Hz}, \mathrm{CHH}^{\prime}\right), 2.33\left(1 \mathrm{H}, \mathrm{dd}, J 11.7,4.2 \mathrm{~Hz}, \mathrm{CHH}^{\prime}\right)$, $3.81\left(1 \mathrm{H}, \mathrm{dd}, J 15.3,4.5 \mathrm{~Hz}, \mathrm{CHH}^{\prime} \mathrm{Ph}\right), 4.19(1 \mathrm{H}, \mathrm{d}, J 4.2 \mathrm{~Hz}, 14-\mathrm{H}), 4.28(1 \mathrm{H}, \mathrm{dd}, J 15.3,8.0$ $\left.\mathrm{Hz}, \mathrm{CHH}^{\prime} \mathrm{Ph}\right), 4.52-4.55(1 \mathrm{H}, \mathrm{m}, 15-\mathrm{H}), 6.34(2 \mathrm{H}, \mathrm{d}, J 7.8 \mathrm{~Hz}, \mathrm{Ar}-\mathrm{H}), 6.58(1 \mathrm{H}, \mathrm{d}, J 7.8 \mathrm{~Hz}, 10-$ H), 6.92-7.12 (6H, m, Ar-H), $7.16(1 \mathrm{H}, \mathrm{d}, J 9.3 \mathrm{~Hz}, 5-\mathrm{H}), 7.19-7.24(2 \mathrm{H}, \mathrm{m}, \mathrm{Ar}-\mathrm{H}), 7.83(1 \mathrm{H}, \mathrm{d}$, 
$J 9.3 \mathrm{~Hz}, 5-\mathrm{H}), 8.17(1 \mathrm{H}, \mathrm{d}, J 9.3 \mathrm{~Hz}, 1-\mathrm{H}), 8.23(1 \mathrm{H}, \mathrm{dd}, J 9.3,2.0 \mathrm{~Hz}, 2-\mathrm{H}), 8.65(1 \mathrm{H}, \mathrm{d}, J 2.0$ $\mathrm{Hz}, 4-\mathrm{H}) .{ }^{13} \mathrm{C} \mathrm{NMR}\left(75 \mathrm{MHz}, \mathrm{CDCl}_{3}\right): \delta_{\mathrm{C}} 23.1,26.4,32.7,37.2,42.5,99.9,109.9,110.4,118.2$, $119.9,120.0,122.4,122.6,124.7,124.9,126.7(2 \times \mathrm{C}), 126.9,127.2,128.2(2 \times \mathrm{C}), 128.4$, $131.4,134.4,134.5,137.3,138.5,143.5,148.8,153.6,169.8(\mathrm{C}=\mathrm{O}) . \mathrm{MS} m / z(\%): 506\left(\mathrm{M}+\mathrm{H}^{+}\right.$, 100). Anal. Calcd for $\mathrm{C}_{31} \mathrm{H}_{27} \mathrm{~N}_{3} \mathrm{O}_{4}(505.56)$ : C, 73.65; H, 5.38; N, 8.31. Found: C, 73.14; H, 5.38; $\mathrm{N}, 8.13 \%$.

$\left(7 \mathrm{a} R^{*}, 14 R^{*}, 15 S^{*}\right)-$ and $\left(7 \mathrm{a} R^{*}, 14 S^{*}, 15 S^{*}\right)-8,8-D i m e t h y l-3-n i t r o-N$-(prop-2-en-1-yl)-14,15dihydro-8H-7a,15-methanonaphtho[ $\left[1^{\prime}, 2^{\prime}: 6,7\right][1,3]$ oxazepino[3,2-a]indole-14-carboxamides (trans-6b and cis-7b). Following the procedure of preparation of $6 \mathbf{a}$ and $7 \mathbf{a}$, the spiropyran $\mathbf{5 b}$ (800 $\mathrm{mg}, 1.75 \mathrm{mmol})$, potassium hydroxide $(295 \mathrm{mg}, 5.26 \mathrm{mmol})$ in ethanol $(25 \mathrm{ml})$ gave isomers trans-6b and cis-7b.

Isomer trans-6b: yellowish crystals, yield $310 \mathrm{mg}(39 \%), \mathrm{mp} 225-226{ }^{\circ} \mathrm{C}$ (from ethanol). IR: $v_{\max } 3412(\mathrm{~N}-\mathrm{H}), 3062,2974,1687 \mathrm{~cm}^{-1}(\mathrm{C}=\mathrm{O}) .{ }^{1} \mathrm{H}$ NMR $\left(400 \mathrm{MHz}, \mathrm{CDCl}_{3}\right): \delta_{\mathrm{H}} 1.35(3 \mathrm{H}, \mathrm{s}$, $\left.\mathrm{CH}_{3}\right), 1.67\left(1 \mathrm{H}, \mathrm{s}, \mathrm{CH}_{3}\right), 2.20\left(1 \mathrm{H}, \mathrm{d}, J 11.6 \mathrm{~Hz}, \mathrm{CHH}^{\prime}\right), 2.61\left(1 \mathrm{H}, \mathrm{dd}, J 11.6,4.0 \mathrm{~Hz}, \mathrm{CHH}^{\prime}\right)$, 3.84-3.98 (2H, m, NHCH 2$) 4.47(1 \mathrm{H}, \mathrm{s}, 14-\mathrm{H}), 4.49(1 \mathrm{H}, \mathrm{d}, J 4.0 \mathrm{~Hz}, 15-\mathrm{H}), 5.05-5.13(2 \mathrm{H}, \mathrm{m}$, $\left.\mathrm{CH}_{2}=\mathrm{CH}\right), 5.73-5.82\left(1 \mathrm{H}, \mathrm{m}, \mathrm{CH}_{2}=\mathrm{CH}\right), 5.97(1 \mathrm{H}, \mathrm{t}, J 5.6 \mathrm{~Hz}, \mathrm{NH}), 6.35(1 \mathrm{H}, \mathrm{d}, J 8.0 \mathrm{~Hz}, 13-\mathrm{H})$, $6.84(1 \mathrm{H}, \mathrm{t}, J 7.6 \mathrm{~Hz}, 12-\mathrm{H}), 7.07(1 \mathrm{H}, \mathrm{t}, J 7.6 \mathrm{~Hz}, 11-\mathrm{H}), 7.09(1 \mathrm{H}, \mathrm{d}, J 8.8 \mathrm{~Hz}, 5-\mathrm{H}), 7.17(1 \mathrm{H}$, d, J 7.6 Hz, 10-H), 7.79 (1H, d, J 8.8 Hz, 6-H), 8.13 (1H, d, J 9.2 Hz, 1-H), 8.25 (1H, dd, J 9.2, $2.4 \mathrm{~Hz}, 2-\mathrm{H}), 8.68(1 \mathrm{H}, \mathrm{d}, J 2.4 \mathrm{~Hz}, 4-\mathrm{H}) .{ }^{13} \mathrm{C} \mathrm{NMR}\left(100 \mathrm{MHz}, \mathrm{CDCl}_{3}\right): \delta_{\mathrm{C}} 20.6,28.27,28.29$, $42.0,42.1,44.8,67.5,107.2,108.1,116.8,120.1,120.4,120.5,121.3,122.8,123.1,125.6,127.2$, 128.2, 131.1, 133.5, 133.7, 141.0, 141.8, 143.5, 154.6, $169.7(\mathrm{C}=\mathrm{O})$. HRMS (ESI TOF): $[\mathrm{M}+\mathrm{H}]^{+}$, found 456.1918. $\left[\mathrm{C}_{26} \mathrm{H}_{25} \mathrm{~N}_{3} \mathrm{O}_{4}+\mathrm{H}\right]^{+}$requires 456.1918.

Isomer cis-7b: yellowish crystals, yield $106 \mathrm{mg}(13 \%), \mathrm{mp}>250{ }^{\circ} \mathrm{C}$ (from acetonitrile). IR: $v_{\max }$ $3293(\mathrm{~N}-\mathrm{H}), 3074,2965,1654 \mathrm{~cm}^{-1}(\mathrm{C}=\mathrm{O}) .{ }^{1} \mathrm{H}$ NMR $\left(400 \mathrm{MHz}, \mathrm{CDCl}_{3}\right): \delta_{\mathrm{H}} 1.54\left(3 \mathrm{H}, \mathrm{s}, \mathrm{CH}_{3}\right)$, $1.57\left(3 \mathrm{H}, \mathrm{s}, \mathrm{CH}_{3}\right), 2.24\left(1 \mathrm{H}, \mathrm{d}, J 11.6 \mathrm{~Hz}, \mathrm{CHH}^{\prime}\right), 2.32\left(1 \mathrm{H}, \mathrm{dd}, J 11.6,4.0 \mathrm{~Hz}, \mathrm{CHH}^{\prime}\right), 3.23-3.29$ $\left(1 \mathrm{H}, \mathrm{m}, \mathrm{NHCHH}^{\prime}\right), 3.50-3.58\left(1 \mathrm{H}, \mathrm{m}, \mathrm{NHCHH}^{\prime}\right), 4.14(1 \mathrm{H}, \mathrm{d}, J 4.0 \mathrm{~Hz}, 14-\mathrm{H}), 4.36$ (1H, ddd, $J$ $16.8,3.2,1.6 \mathrm{~Hz}$, trans- $\mathrm{CH} H=\mathrm{CH}), 4.507-4.55(2 \mathrm{H}, \mathrm{m}, 15-\mathrm{H}$, cis- $\mathrm{CH} H=\mathrm{CH}), 4.79-4.89(1 \mathrm{H}, \mathrm{m}$, $\left.\mathrm{CH}_{2}=\mathrm{CH}\right), 6.56(1 \mathrm{H}, \mathrm{d}, J 7.6 \mathrm{~Hz}, 13-\mathrm{H}), 6.94-6.97(1 \mathrm{H}, \mathrm{m}, \mathrm{NH}), 6.99(1 \mathrm{H}, \mathrm{dt}, J 7.6,0.8 \mathrm{~Hz}, 12-$ H), 7.13-7.19 (2H, m, 10-H, 11-H), $7.22(1 \mathrm{H}, \mathrm{d}, J 9.6 \mathrm{~Hz}, 5-\mathrm{H}), 7.87$ (1H, d, J 8.8 Hz, 6-H), 8.15 $(1 \mathrm{H}, \mathrm{d}, J 9.6 \mathrm{~Hz}, 1-\mathrm{H}), 8.25(1 \mathrm{H}, \mathrm{dd}, J 9.6,2.4 \mathrm{~Hz}, 2-\mathrm{H}), 8.68(1 \mathrm{H}, \mathrm{d}, J 2.4 \mathrm{~Hz}, 4-\mathrm{H}) .{ }^{13} \mathrm{C}$ NMR $\left(100 \mathrm{MHz}, \mathrm{CDCl}_{3}\right): \delta_{\mathrm{C}} 23.3,26.6,32.8,37.5,41.0,45.1,78.5,110.2,110.6,115.6,118.5,120.1$, $120.2,122.5,122.8,124.8,124.9,127.5,128.6,131.6,133.4,134.7,138.7,143.8,148.9,153.8$, $169.9(\mathrm{C}=\mathrm{O})$. HRMS (ESI TOF): $[\mathrm{M}+\mathrm{H}]^{+}$, found 456.1920. $\left[\mathrm{C}_{26} \mathrm{H}_{25} \mathrm{~N}_{3} \mathrm{O}_{4}+\mathrm{H}\right]^{+}$requires 456.1918. $\left(7 \mathrm{a} R^{*}, 14 R^{*}, 15 S^{*}\right)-$ and $\left(7 \mathrm{a} R^{*}, 14 S^{*}, 15 S^{*}\right)-N, 8,8$-Trimethyl-3-nitro-14,15-dihydro-8H-7a,15methanonaphtho[1',2':6,7][1,3] oxazepino[3,2-a]indole-14-carboxamides (trans-6c and cis7c). Following the procedure of preparation of $\mathbf{6 a}$ and $7 \mathbf{a}$, the spiropyran $\mathbf{5 c}(1.1 \mathrm{~g}, 2.56 \mathrm{mmol})$, potassium hydroxide $(0.43 \mathrm{~g}, 7.68 \mathrm{mmol})$ in ethanol $(25 \mathrm{ml})$ gave trans-6c and cis-7c.

Isomer trans-6c: yellowish crystals, yield $0.46 \mathrm{~g}(42 \%), \mathrm{mp} 251-253{ }^{\circ} \mathrm{C}$ (from ethanol). IR: $v_{\max }$ $3404(\mathrm{~N}-\mathrm{H}), 3025,2991,1687 \mathrm{~cm}^{-1}(\mathrm{C}=\mathrm{O}) .{ }^{1} \mathrm{H}$ NMR $\left(300 \mathrm{MHz}, \mathrm{DMSO}-d_{6}\right): \delta_{\mathrm{H}} 1.38(3 \mathrm{H}, \mathrm{s}$, $\left.\mathrm{CH}_{3}\right), 1.58\left(3 \mathrm{H}, \mathrm{s}, \mathrm{CH}_{3}\right), 2.07\left(1 \mathrm{H}, \mathrm{d}, J 11.7 \mathrm{~Hz}, \mathrm{CHH}^{\prime}\right), 2.65\left(3 \mathrm{H}, \mathrm{d}, J 4.2 \mathrm{~Hz}, \mathrm{CH}_{3}\right), 3.05(1 \mathrm{H}$, 
dd, $\left.J 11.7,4.5 \mathrm{~Hz}, \mathrm{CHH}^{\prime}\right), 4.33(1 \mathrm{H}, \mathrm{d}, J 4.2 \mathrm{~Hz}, 15-\mathrm{H}), 4.39(1 \mathrm{H}, \mathrm{s}, 14-\mathrm{H}), 6.18(1 \mathrm{H}, \mathrm{d}, J 7.5$ $\mathrm{Hz}, 13-\mathrm{H}), 6.68(1 \mathrm{H}, \mathrm{t}, J 7.5 \mathrm{~Hz}, 11-\mathrm{H}), 6.94(1 \mathrm{H}, \mathrm{dt}, J 7.5,0.9 \mathrm{~Hz}, 12-\mathrm{H}), 7.10(1 \mathrm{H}, \mathrm{d}, J 7.5 \mathrm{~Hz}$, 10-H), $7.18(1 \mathrm{H}, \mathrm{d}, J 9.0 \mathrm{~Hz}, 6-\mathrm{H}), 8.10(1 \mathrm{H}, \mathrm{d}, J 9.0 \mathrm{~Hz}, 5-\mathrm{H}), 8.22-8.29(2 \mathrm{H}, \mathrm{m}, 1-\mathrm{H}, 2-\mathrm{H})$, 8.36-8.37 $(1 \mathrm{H}, \mathrm{m}, \mathrm{NH}), 8.92(1 \mathrm{H}, \mathrm{d}, J 1.8 \mathrm{~Hz}, 4-\mathrm{H}) .{ }^{13} \mathrm{C}$ NMR $\left(75 \mathrm{MHz}, \mathrm{DMSO}-d_{6}\right): \delta_{\mathrm{C}} 21.2$, 25.5, 28.1, 40.9, 44.5, 67.2 106.9, 107.7, 118.6, 119.6, 119.9, 121.0, 121.2, 122.2, 123.9, 125.3, $126.6,127.4,131.3,133.4,141.0,142.7,143.1,154.3,169.2(\mathrm{C}=\mathrm{O}) . \mathrm{MS} m / z(\%): 430\left(\mathrm{M}+\mathrm{H}^{+}\right.$, 100). Anal. Calcd for $\mathrm{C}_{25} \mathrm{H}_{23} \mathrm{~N}_{3} \mathrm{O}_{4}$ (429.47): C, 69.92; H, 5.40; N, 9.78. Found: C, 69.64; H, 5.51; $\mathrm{N}, 9.47 \%$.

Isomer cis-7c: yellowish crystals, yield $0.185 \mathrm{~g}(17 \%), \mathrm{mp} 272-273{ }^{\circ} \mathrm{C}$ (from acetonitrile). IR $\left(v_{\max }, \mathrm{cm}^{-1}\right): 3296(\mathrm{~N}-\mathrm{H}), 3046,2967,1654(\mathrm{C}=\mathrm{O}) .{ }^{1} \mathrm{H}$ NMR $\left(300 \mathrm{MHz}, \mathrm{CDCl}_{3}\right): \delta_{\mathrm{H}} 1.53(3 \mathrm{H}, \mathrm{s}$, $\left.\mathrm{CH}_{3}\right), 1.56\left(3 \mathrm{H}, \mathrm{s}, \mathrm{CH}_{3}\right), 2.22\left(1 \mathrm{H}, \mathrm{d}, J 11.7 \mathrm{~Hz}, \mathrm{CHH}^{\prime}\right), 2.24\left(3 \mathrm{H}, \mathrm{d}, J 5.1 \mathrm{~Hz}, \mathrm{NCH}_{3}\right), 2.32(1 \mathrm{H}$, dd, J 11.7, 4.2 Hz, CHH'), $4.12(1 \mathrm{H}, \mathrm{d}, J 4.8 \mathrm{~Hz}, 14-\mathrm{H}), 4.50(1 \mathrm{H}, \mathrm{t}, J 4.2 \mathrm{~Hz}, 15-\mathrm{H}), 6.53$ (1H, d, $J 7.5 \mathrm{~Hz}, 13-\mathrm{H}), 6.77-6.82(1 \mathrm{H}, \mathrm{m}, \mathrm{NH}), 6.98(1 \mathrm{H}, \mathrm{dt}, J 7.5,0.9 \mathrm{~Hz}, 12-\mathrm{H}), 7.12-7.18(2 \mathrm{H}, \mathrm{m}$, 10-H, 11-H), $7.21(1 \mathrm{H}, \mathrm{d}, J 9.0 \mathrm{~Hz}, 6-\mathrm{H}), 7.85(1 \mathrm{H}, \mathrm{d}, J 9.0 \mathrm{~Hz}, 5-\mathrm{H}), 8.15(1 \mathrm{H}, \mathrm{d}, J 9.3 \mathrm{~Hz}, 1-$ H), $8.24(1 \mathrm{H}, \mathrm{dd}, J 9.3,2.4 \mathrm{~Hz}, 2-\mathrm{H}), 8.65(1 \mathrm{H}, \mathrm{d}, J 2.4 \mathrm{~Hz}, 4-\mathrm{H}) .{ }^{13} \mathrm{C}$ NMR $\left(75 \mathrm{MHz}, \mathrm{CDCl}_{3}\right)$ : $\delta_{\mathrm{C}} 23.1,25.5,26.4,32.6,37.3,44.9,78.3,110.0,110.4,118.3,119.8,120.0,122.3,122.6,124.6$, $124.8,127.1,128.3,131.4,134.3,138.4,143.6,148.7,153.5,170.6(\mathrm{C}=\mathrm{O}) . \mathrm{MS} m / z(\%): 430$ $\left(\mathrm{M}+\mathrm{H}^{+}, 100\right)$. Anal. Calcd for $\mathrm{C}_{25} \mathrm{H}_{23} \mathrm{~N}_{3} \mathrm{O}_{4}$ (429.47): C, 68.48; H, 5.52; N, 9.58. Found: C, 68.43; $\mathrm{H}, 5.41 ; \mathrm{N}, 9.47 \%$.

$\left(7 \mathrm{a} R^{*}, 14 R^{*}, 15 S^{*}\right)-$ and $\left(7 \mathrm{a} R^{*}, 14 S^{*}, 15 S^{*}\right)-N, 8,8,10$-Tetramethyl-3-nitro-14,15-dihydro-8H7a,15-methanonaphtho[1',2':6,7][1,3]oxazepino[3,2-a]indole-14-carboxamides (trans-6d and cis-7d). Following the procedure of preparation of $\mathbf{6 a}$ and $7 \mathbf{a}$, the spiropyran $\mathbf{5 d}(1.0 \mathrm{~g}, 2.25$ $\mathrm{mmol})$, potassium hydroxide $(380 \mathrm{mg}, 6.75 \mathrm{mmol})$ in ethanol $(25 \mathrm{ml})$ gave trans $-\mathbf{6 d}$ and cis-7d.

Isomer trans-6d: yellowish crystals, yield $380 \mathrm{mg}(59 \%), \mathrm{mp} 241-243{ }^{\circ} \mathrm{C}$ (from ethanol). IR: $v_{\max } 3400(\mathrm{~N}-\mathrm{H}), 3065,2975,1685 \mathrm{~cm}^{-1}(\mathrm{C}=\mathrm{O}) .{ }^{1} \mathrm{H}$ NMR $\left(300 \mathrm{MHz}, \mathrm{CDCl}_{3}\right): \delta_{\mathrm{H}} 1.37(3 \mathrm{H}, \mathrm{s}$, $\left.\mathrm{CH}_{3}\right), 1.56\left(3 \mathrm{H}, \mathrm{s}, \mathrm{CH}_{3}\right), 2.05\left(1 \mathrm{H}, \mathrm{d}, J 11.4 \mathrm{~Hz}, \mathrm{CHH}^{\prime}\right), 2.19\left(3 \mathrm{H}, \mathrm{s}, 11-\mathrm{CH}_{3}\right), 2.63(3 \mathrm{H}, \mathrm{d}, J 4.5$ $\left.\mathrm{Hz}, \mathrm{NH}-\mathrm{CH}_{3}\right), 3.06\left(1 \mathrm{H}, \mathrm{dd}, J 11.4,4.6 \mathrm{~Hz}, \mathrm{CHH}^{\prime}\right), 4.30(1 \mathrm{H}, \mathrm{d}, J 4.6 \mathrm{~Hz}, 15-\mathrm{H}), 4.36$ (1H, s, 14H), $6.07(1 \mathrm{H}, \mathrm{d}, J 7.5 \mathrm{~Hz}, 13-\mathrm{H}), 6,74(1 \mathrm{H}, \mathrm{dd}, J 7.5,0.6 \mathrm{~Hz}, 12-\mathrm{H}), 6.92(1 \mathrm{H}, \mathrm{d}, J 1.5 \mathrm{~Hz}, 10-\mathrm{H})$, 7,17 (1H, d, J 9.0 Hz, 5-H), 8.10 (1H, d, J 9.0 Hz, 6-H), 8.24-8.25 (2H, m, 1-H, 2-H), 8.33-8.37 $(1 \mathrm{H}, \mathrm{m}, \mathrm{NH}), 8.92(1 \mathrm{H}, \mathrm{d}, J 1.5 \mathrm{~Hz}, 4-\mathrm{H}) .{ }^{13} \mathrm{C} \mathrm{NMR}\left(75 \mathrm{MHz}, \mathrm{CDCl}_{3}\right): \delta_{\mathrm{C}} 20.7,21.6,25.5,28.0$, 28.4, 40.9, 44.5, 67.7, 106.9, 108.3, 119.7, 121.1, 121.3, 123.0, 123.9, 125.4, 126.7, 127.37, 127.6, 131.3, 133.5, 141.0, 141.2, 142.8, 154.4, $169.3(\mathrm{C}=\mathrm{O})$. Anal. Calcd for $\mathrm{C}_{26} \mathrm{H}_{25} \mathrm{~N}_{3} \mathrm{O}_{4}$ (443.49): C, 70.41; H, 5.68; N, 9.47. Found: C, 70.03; H, 5.78; N, 9.36\%. HRMS (ESI TOF): $[\mathrm{M}+\mathrm{H}]^{+}$, found 444.1919. $\left[\mathrm{C}_{26} \mathrm{H}_{25} \mathrm{~N}_{3} \mathrm{O}_{4}+\mathrm{H}\right]^{+}$requires 444.1918.

Isomer cis-7d: yellowish crystals, yield $82 \mathrm{mg}(8 \%), \mathrm{mp}>250{ }^{\circ} \mathrm{C}$ (from acetonitrile). IR ( $v_{\max }$, $\left.\mathrm{cm}^{-1}\right): 3320(\mathrm{~N}-\mathrm{H}), 3025,2965,1652(\mathrm{C}=\mathrm{O}) .{ }^{1} \mathrm{H}$ NMR $\left(400 \mathrm{MHz}, \mathrm{DMSO}-d_{6}\right): \delta_{\mathrm{H}} 1.46(3 \mathrm{H}, \mathrm{s}$, $\left.\mathrm{CH}_{3}\right), 1.50\left(3 \mathrm{H}, \mathrm{s}, \mathrm{CH}_{3}\right), 2.07\left(3 \mathrm{H}, \mathrm{d}, J 4.8 \mathrm{~Hz}, \mathrm{NH}-\mathrm{CH}_{3}\right), 2.12\left(1 \mathrm{H}, \mathrm{d}, J 11.6 \mathrm{~Hz}, \mathrm{CHH}^{\prime}\right), 2.25$ $\left(3 \mathrm{H}, \mathrm{s}, \mathrm{CH}_{3}\right), 2.30\left(1 \mathrm{H}, \mathrm{dd}, J 11.6,4.8 \mathrm{~Hz}, \mathrm{CHH}^{\prime}\right), 3.94(1 \mathrm{H}, \mathrm{d}, J 4.8 \mathrm{~Hz}, 14-\mathrm{H}), 4.49$ (1H, t, J 4.8 $\mathrm{Hz}, 15-\mathrm{H}), 6.30(1 \mathrm{H}, \mathrm{d}, J 7.6 \mathrm{~Hz}, \mathrm{Ar}-\mathrm{H}), 6.92(1 \mathrm{H}, \mathrm{d}, J 7.6 \mathrm{~Hz}, \mathrm{Ar}-\mathrm{H}), 7.01(1 \mathrm{H}, \mathrm{s}, \mathrm{Ar}-\mathrm{H}), 7.27$ $(1 \mathrm{H}, \mathrm{d}, J 8.8 \mathrm{~Hz}, \mathrm{Ar}-\mathrm{H}), 7.54-7.57(1 \mathrm{H}, \mathrm{m}, \mathrm{NH}), 8.11(1 \mathrm{H}, \mathrm{d}, J 9.2 \mathrm{~Hz}, \mathrm{Ar}-\mathrm{H}), 8.15(1 \mathrm{H}, \mathrm{s}$, Ar- 
H), $8.87(1 \mathrm{H}, \mathrm{s}, \mathrm{Ar}-\mathrm{H}) .{ }^{13} \mathrm{C}$ NMR $\left(100 \mathrm{MHz}, \mathrm{DMSO}-d_{6}\right): \delta_{\mathrm{C}} 20.6,23.1,25.3,26.1,32.0,36.9$, 44.32, 77.7, 99.5, 109.7, 110.0, 118.8, 120.1, 122.8, 124.8, 125.1, 126.7, 128.3, 130.0, 131.4, 134.1, 138.5, 142.7, 146.8, 153.6, 169.7. HRMS (ESI TOF): $[\mathrm{M}+\mathrm{H}]^{+}$, found 444.1919. $\left[\mathrm{C}_{26} \mathrm{H}_{25} \mathrm{~N}_{3} \mathrm{O}_{4}+\mathrm{H}\right]^{+}$requires 444.1918 .

\section{Acknowledgements}

This study was funded by a grant (No. MIP-076/2012) from the Research Council of Lithuania.

\section{References}

1. Crano, J. C.; Guglielmetti R. J. Eds. Organic Photochromic and Thermochromic Compounds; Plenum Press: New York, 1999; Vol. 1, p. 400.

2. Minkin V. I. Chem. Rev. 2004, 104, 2751. http://dx.doi.org/10.1021/cr020088u

3. Barachevsky, V. A.; Strokach, Y. P.; Puankov, Y. A.; Kobeleva, O. I.; Valova, T. M.; Levchenko, K. S.; Yaroshenko, V. N.; Krayushkin, M. M. Arkivoc 2009, (ix), 70.

4. Sheng, L.; Li, M.; Zhu, S.; Li, H.; Xi, G.; Li, Y.-G.; Wang, Y.; Li, Q.; Liang, S.; Zhong, K.; Zhang, S. X.-A. Nat. Commun. 2014, 5, 3044, and references cited therein. http://dx.doi.org/10.1038/ncomms4044

5. Klajn, R. Chem. Soc. Rev. 2013, 43, 148. http://dx.doi.org/10.1039/c3es60181a

6. Chan, Y.-H.; Gallina M. E.; Zhang, X.; Wu, I.-C.; Jin, Y.; Sun, W.; Chiu, D. T. Anal. Chem. 2012, 84, 9431 .

7. Jonsson, F.; Beke-Somfai, T.; Andréasson, J.; Nordén, B. Langmuir 2013, 29, 2099.

8. Velema, W.A.; Van der Berg, J. P.; Hansen, M. J.; Szymanski, W.; Driessen, A. J. M.; Feringa, B. L. Nat. Chem. 2013, 5, 924.

http://dx.doi.org/10.1038/nchem.1750

9. Lenoble, C.; Becker, R. S. J. Phys. Chem. 1986, 90, 62. http://dx.doi.org/10.1021/j100273a015

10. Görner, H. Phys. Chem. Chem. Phys. 2001, 3, 416. http://dx.doi.org/10.1039/b007708i

11. Lukyanov, B. S.; Lukyanova, M. B. Chem. Heterocycl. Compd. 2005; 41, 281. http://dx.doi.org/10.1007/s10593-005-0148-x

12. Valaitytè, E.; Martynaitis, V.; Šačkus, A. Khim. Geterotsikl. Soed. 2004, 1690.

13. Kellmann, A.; Tfibel, F. J. Photochem. Photobiol. A 1993, 76, 77. http://dx.doi.org/10.1016/1010-6030(93)80176-A 
14. Voloshin, N. A.; Raskita, I. M.; Metelitsa, A. V.; Minkin, V. I. J. Photochem. Photobiol. A 2006, 184, 289.

http://dx.doi.org/10.1016/j.jphotochem.2006.04.042

15. Kleizienė, N.; Martynaitis, V.; Berg, U.; Šačkus, A. Khim. Geterotsikl. Soed. $2001,561$.

16. Martynaitis, V.; Šačkus, A.; Berg, U. J. Heterocycl. Chem. 2002, 39, 1123. http://dx.doi.org/10.1002/jhet.5570390602

17. Machtejevas, E.; Sellergren, B.; Martynaitis, V.; Owens, P. K.; Maruška, A. J. Sep. Sci. 2004, 27, 547.

http://dx.doi.org/10.1002/jssc.200301675

18. Tomasulo, M.; Sortino, S.; White, A. J.; Raymo, F. M. J. Org. Chem. 2005, 70, 8180. http://dx.doi.org/10.1021/jo051417w

19. Barkauskas, M.; Martynaitis, V.; Šačkus, A.; Rotomskis, R.; Sirutkaitis, V.; Vengris, M. Lith. J. Phys. 2008, 48, 231.

http://dx.doi.org/10.3952/lithjphys.48311

20. Tomasulo, M.; Sortino, S.; Raymo, F. M. J. Org. Chem. 2008, 73, 118. http://dx.doi.org/10.1021/jo7017119

21. Dagilienè, M.; Martynaitis, V.; Vengris, M.; Redeckas, K.; Voiciuk, V.; Holzer, W.; Šačkus, A. Tetrahedron 2013, 69, 9309. http://dx.doi.org/10.1016/j.tet.2013.08.020

22. Prostota, Y.; Coelho, P. J.; Pina, J.; de Melo, J. S. Photochem. Photobiol. Sci. 2011, 10, 1346. http://dx.doi.org/10.1039/c1pp05067b

23. Deniz, E.; Sortino, S.; Raymo, F. M. J. Phys. Chem. Lett. 2010, 1, 1690. http://dx.doi.org/10.1021/jz100510u

24. Tomasulo, M.; Yildiz, I.; Kaanumalle, S. L.; Raymo, F. R. Langmuir 2006, 22, 10284. http://dx.doi.org/10.1021/la0618014

25. Tomasulo, M.; Sortino, S.; White, A. J. P.; Raymo, F.M. J. Org. Chem. 2006, 71, 744. http://dx.doi.org/10.1021/jo052096r

26. Ren, J.; Zhu, W.; Tian, H. Talanta 2008, 75, 760. http://dx.doi.org/10.1016/j.talanta.2007.12.024

27. Shachkus, A. A.; Degutis, Y. A. Chem. Heterocycl. Compd. 1988, 24, 4.

28. Kleizienè, N.; Amankavičienè, V.; Berg, U.; Schicktanz, C.; Schlothauer, K.; Šačkus, A. Monatsh. Chem. 2006, 137, 1109. http://dx.doi.org/10.1007/s00706-005-0504-7

29. Šačkus, A.; Valaitytė, E.; Amankavičienė, V.; Berg, U.; Schicktanz, C.; Schlothauer, K. Khim. Geterotsikl. Soed. 2007, 1322.

30. The CCDC deposition number of $\left(7 \mathrm{a} R^{*}, 14 R^{*}, 15 S^{*}\right)-N$-benzyl-8,8-dimethyl-3-nitro-14,15dihydro-8H-7a,15-methanonaphtho[1',2':6,7][1,3] oxazepino[3,2-a]indole-14-carboxamide (trans-6a) is 910510; formula $\mathrm{C}_{31} \mathrm{H}_{27} \mathrm{~N}_{3} \mathrm{O}_{4}$ unit cell parameters: a 9.2161(3), b 18.9062(8), c 14.7370(7), beta 102.609(2), space group P21/a. 
31. Allen, F.H.; Kennard, O.; Watson, D.G.; Brammer, L.; Orpen, A. G.; Taylor, R. J. Chem. Soc., Perkin II 1987, S1-S19. http://dx.doi.org/10.1039/p298700000s1

32. The CCDC deposition number of $\left(7 \mathrm{a} R^{*}, 14 S^{*}, 15 S^{*}\right)-N$-benzyl-8,8-dimethyl-3-nitro-14,15dihydro-8H-7a,15-methanonaphtho[1',2':6,7][1,3] oxazepino[3,2-a]indole-14-carboxamide (cis-7a) is 909343; formula $2\left(\mathrm{C}_{31} \mathrm{H}_{27} \mathrm{~N}_{3} \mathrm{O}_{4}\right) \cdot \mathrm{C}_{2} \mathrm{H}_{3} \mathrm{~N}$ unit cell parameters: a $12.8399(7)$, b 22.2770(11), c 18.3975(11), space group P21/c.

33. Robinson, B. J. Chem. Soc. 1963, 586.

34. Keum, S.-R.; Lee, M.-J. Bull. Korean Chem. Soc. 1999, 20, 1464.

35. Altomare, A.; Cascarano, G.; Giacovazzo, C.; Guagliardi, A.; Burla, A. M. C.; Polidori, G.; Camalli, M. J. Appl. Crystallogr. 1994, 27, 435.

36. van Stokkum, I. H. M.; Larsen, D. S.; van Grondele, R. Biochim. Biophys. Acta 2004, 1657, 82.

http://dx.doi.org/10.1016/j.bbabio.2004.04.011

37. Bensasson, R. V.; Gramain, J.-C. J. Chem. Soc., Faraday Trans. 1 1980, 76, 1801. http://dx.doi.org/10.1039/f19807601801 